Received: 19 September 2018

Accepted: 18 February 2019

Published online: 11 March 2019

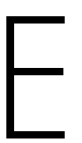

C N
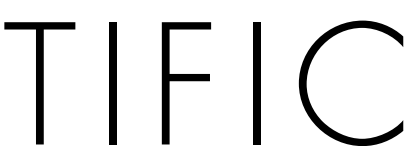

REP

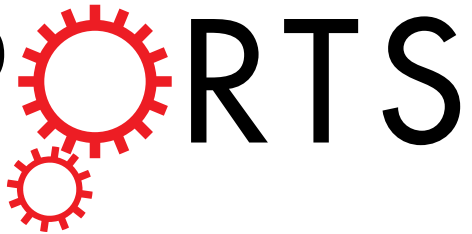

OPEN

\title{
Combined application of selected heavy metals and EDTA reduced the growth of Petunia hybrida L.
}

Aqib Hassan Ali Khan ${ }^{1}$, Tayyab Ashfaq Butt ${ }^{2}$, Cyrus Raza Mirza ${ }^{2}$, Sohail Yousaf ${ }^{1}$, Ismat Nawaz ${ }^{3}$ \& Mazhar lqbal ${ }^{1}$

Up till now, despite of well-developed ornamental market, very little information is available on Petunia hybrida $\mathrm{L}$. tolerance against heavy metals (HMs), which can contribute in both beautification of urban dwellings, as well as potential in phytoremediation. Therefore, hydroponic study was conducted to check the effects of $\mathrm{Cd}, \mathrm{Cr}, \mathrm{Cu}, \mathrm{Ni}$ and $\mathrm{Pb}$ individually $(50$ and $100 \mu \mathrm{M}$ ) and with co-application of EDTA $(2.5 \mathrm{mM})$ in Hoagland's nutrient solution. Results indicated higher uptake of $\mathrm{Cd}, \mathrm{Cr}, \mathrm{Ni}$ and $\mathrm{Pb}$ in above ground parts, and Cu in roots, further the co-application of EDTA enhanced HMs uptake in P. hybrida L. This uptake accompanied changes in biochemical stress indicators, included significantly higher MDA, $\mathrm{H}_{2} \mathrm{O}_{2}$ contents and electrolyte leakage with reduced chlorophyll a, chlorophyll b, total chlorophyll and carotenoid content. Upon exposure to HMs increased antioxidant enzyme activities (CAT, POX, GST, APX, and SOD) were noted. Though selected HMs can be removed by using $P$. hybrida L., the findings of current study indicated that the direct exposure of $P$. hybrida $\mathrm{L}$. to $\mathrm{Cd}, \mathrm{Cr}, \mathrm{Cu}, \mathrm{Ni}$ and $\mathrm{Pb}$ damaged the plant's aesthetics, and to use $P$. hybrida $L$. for beautification of urban landscape or phytoremediation, appropriate soil modification should be included.

With the increase in human population, ecological threats associated with the pollution have also escalated ${ }^{1,2}$. Among the responsible agents that are deteriorating the environment, include the heavy metals (HMs) ${ }^{3,4}$. They are known to accumulate to alarming levels in food chain through the soil contamination ${ }^{5}$. Some of these (like $\mathrm{Cd}, \mathrm{Pb}$, and $\mathrm{Hg}$ ) are not necessary, while others (like $\mathrm{Cu}, \mathrm{Fe}, \mathrm{Mn}, \mathrm{Zn}$, and $\mathrm{Mo}$ ) act as essential micronutrients for plant growth, and excess concentrations affect plant development as well as wide range of physiological and biochemical processes ${ }^{6}$. Phytoremediation is the use of plants (with or without the associated microorganism) for the treatment of notorious contaminants. It has been widely accepted and applied in last few years. As this methodology is cost effective, sustainable, eco-friendly, non-intrusive, it is expected to play crucial role at industrial scale, if implemented with proper consideration (type of pollutant, seasonal variation, composition of waste generated, and variety of plants used $)^{7,8}$. Though metallophytes, notably hyperaccumulators are attractive option for the removal of HMs, but the associated problems of low biomass production and slow growth as the demerits ${ }^{1}$. In last few decades much of the attention was given to crop plants, while pint-sized information is available for ornamental plants and the effect of HMs on them ${ }^{9}$.

Ornamental plants have distinct advantages over robust crops. Compared to crop plants, they offer reduced risk of bioaccumulation of the HMs in the food chain, if they are found to show hyper/accumulation or tolerance capacities $^{10}$. Their use can also redecorate the aesthetics of the polluted sites at the same time that provide them distinction over other hyper/accumulators ${ }^{1}$. The other scenario that can be developed with ornamental plants is that they will suffer with HMs toxicity. With the improved standards for life style and urban structuring, to a greater extent, ornamental plant can be used in parks, streets and other urban surroundings and there will be an expected increase in different HMs sources such as treated waste water for irrigation, automobile, and industries waste exposure ${ }^{9}$.

To identify the tolerance potential of ornamental plant, a robust and thorough screening is needed. Therefore, an exhaustive screening of potential candidate plants is warranted for any effective application

${ }^{1}$ Department of Environmental Sciences, Faculty of Biological Sciences, Quaid-i-Azam University, 45320, Islamabad, Pakistan. ${ }^{2}$ Department of Architectural Engineering, College of Engineering, University of Hail, Hail, Saudi Arabia. ${ }^{3}$ Department of Environmental Sciences, Biotechnology Program, COMSATS University Islamabad, Abbottabad Campus, Abbottabad, Pakistan. Correspondence and requests for materials should be addressed to M.I. (email: miqbal@qau.edu.pk) 


\begin{tabular}{|c|c|c|c|c|c|c|c|c|c|c|}
\hline & $\begin{array}{l}\text { Total leaves } \\
\text { plant }^{-1}\end{array}$ & $\begin{array}{l}\text { Leaf Area } \\
\left(\mathrm{cm}^{2}\right)\end{array}$ & \begin{tabular}{|l|} 
Leaf fresh \\
weight (g)
\end{tabular} & \begin{tabular}{|l|} 
Leaf dried \\
weight (g)
\end{tabular} & $\begin{array}{l}\text { Root length } \\
(\mathrm{cm})\end{array}$ & \begin{tabular}{|l|} 
Root Fresh \\
weight (g)
\end{tabular} & $\begin{array}{l}\text { Root dried } \\
\text { weight (g) }\end{array}$ & $\begin{array}{l}\text { Shoot length } \\
(\mathrm{cm})\end{array}$ & $\begin{array}{l}\text { Shoot fresh } \\
\text { weight }(\mathrm{g})\end{array}$ & $\begin{array}{l}\text { Shoot dried } \\
\text { weight }(\mathrm{g})\end{array}$ \\
\hline Control $^{a}$ & $\begin{array}{l}25.00 \pm 1.00 \\
\text { a12345 }\end{array}$ & $\begin{array}{l}15.25 \pm 1.72 \\
\text { a12345 }\end{array}$ & $\begin{array}{l}36.55 \pm 1.12 \\
\text { a12345 }\end{array}$ & $\begin{array}{l}5.24 \pm 0.27 \\
\text { a12345 }\end{array}$ & $\begin{array}{l}31.39 \pm 1.07 \\
\text { a12345 }\end{array}$ & $\begin{array}{l}7.96 \pm 0.32 \\
\text { a12345 }\end{array}$ & $\begin{array}{l}1.01 \pm 0.03 \\
\text { a12345 }\end{array}$ & $\begin{array}{l}30.29 \pm 1.27 \\
\text { a12345 }\end{array}$ & $\begin{array}{l}25.21 \pm 14.65 \\
\text { a12345 }\end{array}$ & $\begin{array}{l}2.71 \pm 0.1 \\
\text { a12345 }\end{array}$ \\
\hline Control + EDTA ${ }^{\mathrm{a}}$ & $\begin{array}{l}19.00 \pm 1.00 \\
\text { b12345 }\end{array}$ & $\begin{array}{l}4.51 \pm 0.23 \\
\mathrm{~b} 2, \mathrm{c} 13, \mathrm{~d} 45\end{array}$ & $\begin{array}{l}10.78 \pm 6.29 \\
\mathrm{c} 123, \mathrm{~d} 45\end{array}$ & $\begin{array}{l}1.24 \pm 0.15 \\
\mathrm{c} 123, \mathrm{~d} 45\end{array}$ & $\begin{array}{l}15.47 \pm 0.98 \\
\text { b13,c245 }\end{array}$ & $\begin{array}{l}3.50 \pm 0.22 \\
\text { b1345, c2 }\end{array}$ & $\begin{array}{l}0.29 \pm 0.06 \\
\text { b134, c25 }\end{array}$ & $\begin{array}{l}12.86 \pm 1.46 \\
\text { b13, c245 }\end{array}$ & $\begin{array}{l}10.03 \pm 5.79 \\
\text { b1345, c2 }\end{array}$ & $\begin{array}{l}1.29 \pm 0.15 \\
\text { b12345 }\end{array}$ \\
\hline $\mathrm{Cd} 50$ & $14.00 \pm 1.00 \mathrm{c}$ & $7.44 \pm 0.98 \mathrm{~b}$ & $18.37 \pm 1.01 \mathrm{~b}$ & $1.69 \pm 0.15 b$ & $11.88 \pm 6.86 c$ & $1.23 \pm 0.04 c$ & $0.30 \pm 0.01 \mathrm{~b}$ & $6.57 \pm 0.35 c$ & $2.74 \pm 0.18 \mathrm{c}$ & $0.53 \pm 0.05 c$ \\
\hline $\mathrm{Cd} 100$ & $13.67 \pm 1.53 \mathrm{c}$ & $5.58 \pm 0.66 c$ & $8.15 \pm 0.24 c$ & $0.42 \pm 0.05 \mathrm{~d}$ & $2.10 \pm 0.40 f^{*}$ & $0.26 \pm 0.04 \mathrm{e}^{*}$ & $0.07 \pm 0.02 \mathrm{~d}$ & $6.20 \pm 0.45 \mathrm{~cd}$ & $0.99 \pm 0.18 \mathrm{~d}$ & $0.09 \pm 0.02 \mathrm{~d}$ \\
\hline Cd 50+EDTA & $9.33 \pm 0.58 \mathrm{~d}$ & $1.11 \pm 0.15 \mathrm{~d}^{*}$ & $3.34 \pm 0.25 \mathrm{~d}$ & $0.42 \pm 0.07 \mathrm{~d}$ & $7.74 \pm 0.55 \mathrm{~d}$ & $0.57 \pm 0.09 \mathrm{~d}$ & $0.19 \pm 0.02 \mathrm{c}$ & $5.06 \pm 0.56 \mathrm{~d}$ & $0.96 \pm 0.15 \mathrm{~d}$ & $0.08 \pm 0.01 \mathrm{~d}$ \\
\hline Cd $100+$ EDTA & $9.00 \pm 1.00 \mathrm{~d}$ & $0.81 \pm 0.03 \mathrm{~d}^{*}$ & $2.32 \pm 0.21 \mathrm{~d}$ & $0.22 \pm 0.01 \mathrm{~d}$ & $6.00 \pm 0.31 \mathrm{e}$ & $0.45 \pm 0.04 \mathrm{de}$ & $0.21 \pm 0.05 c$ & $3.24 \pm 0.08 \mathrm{e}^{*}$ & $0.21 \pm 0.04 \mathrm{~d}^{*}$ & $0.03 \pm 0.01 \mathrm{~d}^{*}$ \\
\hline Cr 50 & $21.00 \pm 1.73 \mathrm{~b}$ & $14.2 \pm 1.10 \mathrm{a}$ & $22.25 \pm 1.99 \mathrm{~b}$ & $2.36 \pm 0.29 b$ & $29.75 \pm 17.2 \mathrm{~b}$ & $5.87 \pm 0.93 \mathrm{~b}$ & $0.61 \pm 0.06 \mathrm{~b}$ & $25.21 \pm 14.59 \mathrm{~b}$ & $19.49 \pm 1.28 \mathrm{c}$ & $1.37 \pm 0.15 \mathrm{~b}$ \\
\hline Cr 100 & $16.00 \pm 1.00 \mathrm{c}$ & $2.46 \pm 0.46 c$ & $6.52 \pm 1.26 \mathrm{~d}$ & $0.27 \pm 0.07 \mathrm{~d}$ & $9.58 \pm 0.80 \mathrm{~d}$ & $1.29 \pm 0.23 \mathrm{~d}$ & $0.17 \pm 0.03 \mathrm{de}$ & $5.50 \pm 0.02 \mathrm{e}$ & $0.83 \pm 0.11 \mathrm{f} 8$ & $0.06 \pm 0.01 \mathrm{e}$ \\
\hline Cr 50+EDTA & $19.00 \pm 1.00 \mathrm{~b}$ & $1.08 \pm 0.03 c^{*}$ & $8.64 \pm 0.10 c$ & $2.36 \pm 0.13 b$ & $9.75 \pm 0.79 \mathrm{~d}$ & $1.54 \pm 0.13 \mathrm{~d}$ & $0.21 \pm 0.04 \mathrm{~cd}$ & $9.55 \pm 0.23 \mathrm{~d}$ & $5.99 \pm 0.17 \mathrm{~d}$ & $0.61 \pm 0.04 \mathrm{c}$ \\
\hline Cr $100+$ EDTA & $16.00 \pm 1.00 \mathrm{c}$ & $1.01 \pm 0.05 c^{*}$ & $6.45 \pm 0.34 \mathrm{~d}$ & $0.86 \pm 0.06 \mathrm{c}$ & $7.58 \pm 0.41 \mathrm{e}$ & $0.99 \pm 0.03 \mathrm{~d}$ & $0.12 \pm 0.02 \mathrm{e}$ & $5.50 \pm 0.49 \mathrm{e}$ & $3.83 \pm 0.88 \mathrm{e}$ & $0.39 \pm 0.10 \mathrm{~d}$ \\
\hline $\mathrm{Cu} 50$ & $13.67 \pm 1.53 c$ & $6.26 \pm 0.08 \mathrm{~b}$ & $13.98 \pm 1.23 \mathrm{~b}$ & $1.69 \pm 0.15 b$ & $14.02 \pm 0.10 \mathrm{c}$ & $1.23 \pm 0.04 \mathrm{c}$ & $0.18 \pm 0.03 c$ & $5.28 \pm 0.42 \mathrm{c}$ & $2.74 \pm 0.18 \mathrm{c}$ & $0.29 \pm 0.04 \mathrm{c}$ \\
\hline $\mathrm{Cu} 100$ & $9.33 \pm 0.58 \mathrm{~d}$ & $4.92 \pm 0.56 c$ & $8.09 \pm 0.21 \mathrm{~d}$ & $0.43 \pm 0.09 \mathrm{~d}$ & $11.19 \pm 0.47 \mathrm{~d}$ & $0.87 \pm 0.10 \mathrm{~d}$ & $0.09 \pm 0.02 \mathrm{~d}$ & $5.87 \pm 0.29 \mathrm{c}$ & $0.92 \pm 0.05 \mathrm{~d}$ & $0.08 \pm 0.02 \mathrm{c}$ \\
\hline $\mathrm{Cu} 50+$ EDTA & $10.00 \pm 1.00 \mathrm{~d}$ & $1.34 \pm 0.04 \mathrm{~d}^{*}$ & $2.32 \pm 0.21 \mathrm{e}$ & $0.16 \pm 0.17 \mathrm{c}$ & $6.00 \pm 0.39 \mathrm{e}$ & $0.75 \pm 0.06 \mathrm{de}$ & $0.12 \pm 0.05 \mathrm{~cd}$ & $6.24 \pm 0.92 \mathrm{c}$ & $0.91 \pm 0.08 \mathrm{~d}$ & $0.09 \pm 0.04 \mathrm{c}$ \\
\hline $\mathrm{Cu} 100+\mathrm{EDTA}$ & $5.67 \pm 0.58 \mathrm{e}^{*}$ & $1.07 \pm 0.04 \mathrm{~d}^{*}$ & $0.63 \pm 0.07 f^{*}$ & $0.05 \pm 0.04 \mathrm{e}^{*}$ & $5.37 \pm 0.28 \mathrm{e}$ & $0.48 \pm 0.04 \mathrm{e}$ & $0.07 \pm 0.02 \mathrm{~d}$ & $5.71 \pm 0.03 c$ & $0.23 \pm 0.07 \mathrm{~d}^{*}$ & $0.03 \pm 0.02 \mathrm{c}^{*}$ \\
\hline $\mathrm{Ni} 50$ & $19.33 \pm 1.53 \mathrm{~b}$ & $12.19 \pm 7.04 \mathrm{~b}$ & $29.79 \pm 1.23 \mathrm{~b}$ & $4.29 \pm 0.20 \mathrm{~b}$ & $19.28 \pm 11.14 b$ & $2.40 \pm 0.52 \mathrm{c}$ & $0.19 \pm 0.11 \mathrm{~b}$ & $18.98 \pm 1.04 \mathrm{~b}$ & $5.92 \pm 0.80 \mathrm{c}$ & $0.62 \pm 0.13 c$ \\
\hline Ni 100 & $17.00 \pm 2.00 \mathrm{~b}$ & $9.67 \pm 0.60 c$ & $21.83 \pm 1.63 \mathrm{c}$ & $2.23 \pm 0.24 c$ & $12.82 \pm 7.48 \mathrm{~d}$ & $1.90 \pm 0.04 \mathrm{~d}$ & $0.25 \pm 0.11 \mathrm{~b}$ & $17.59 \pm 1.06 \mathrm{~b}$ & $4.47 \pm 0.33 \mathrm{~d}$ & $0.30 \pm 0.03 \mathrm{~d}$ \\
\hline $\mathrm{Ni} 50+$ EDTA & $11.00 \pm 1.00 \mathrm{c}$ & $2.84 \pm 0.31 \mathrm{e}$ & $10.7 \pm 0.89 \mathrm{~d}$ & $1.12 \pm 0.03 \mathrm{~d}$ & $6.65 \pm 0.52 \mathrm{e}$ & $0.62 \pm 0.10 \mathrm{e}$ & $0.06 \pm 0.01 c$ & $6.68 \pm 0.14 \mathrm{~d}$ & $0.84 \pm 0.02 \mathrm{e}$ & $0.07 \pm 0.01 \mathrm{e}$ \\
\hline Ni 100+EDTA & $9.67 \pm 0.58 \mathrm{c}$ & $2.73 \pm 0.37 \mathrm{e}$ & $8.9 \pm 0.40 \mathrm{e}$ & $0.73 \pm 0.05 \mathrm{e}$ & $5.49 \pm 0.13 \mathrm{e}$ & $0.34 \pm 0.03 \mathrm{e}$ & $0.03 \pm 0.01 c^{*}$ & $6.02 \pm 0.52 \mathrm{~d}$ & $0.68 \pm 0.03 \mathrm{e}$ & $0.07 \pm 0.01 \mathrm{e}$ \\
\hline $\mathrm{Pb} 50$ & $22.33 \pm 1.53 \mathrm{~b}$ & $11.85 \pm 6.84 \mathrm{~b}$ & $28.19 \pm 1.29 \mathrm{~b}$ & $4.13 \pm 0.64 \mathrm{~b}$ & $20.04 \pm 1.57 \mathrm{~b}$ & $2.30 \pm 0.41 \mathrm{~cd}$ & $0.35 \pm 0.04 \mathrm{~b}$ & $17.6 \pm 10.21 \mathrm{~b}$ & $7.35 \pm 0.49 \mathrm{bc}$ & $0.74 \pm 0.12 \mathrm{bc}$ \\
\hline $\mathrm{Pb} 100$ & $17.00 \pm 1.00 \mathrm{bc}$ & $10.00 \pm 0.31 \mathrm{c}$ & $21.83 \pm 1.03 c$ & $1.94 \pm 0.40 \mathrm{c}$ & $18.02 \pm 1.24 \mathrm{bc}$ & $1.90 \pm 0.16 \mathrm{de}$ & $0.15 \pm 0.02 \mathrm{c}$ & $14.59 \pm 8.52 \mathrm{c}$ & $5.47 \pm 0.33 c$ & $0.48 \pm 0.03 \mathrm{~cd}$ \\
\hline $\mathrm{Pb} 50+\mathrm{EDTA}$ & $16.00 \pm 2.00 \mathrm{bc}$ & $4.34 \pm 0.07 \mathrm{de}$ & $10.70 \pm 0.59 \mathrm{~d}$ & $0.98 \pm 0.06 \mathrm{~d}$ & $11.32 \pm 0.08 \mathrm{~d}$ & $1.83 \pm 0.09 \mathrm{de}$ & $0.09 \pm 0.02 \mathrm{c}$ & $8.84 \pm 0.21 \mathrm{~d}$ & $3.89 \pm 0.08 \mathrm{~cd}$ & $0.54 \pm 0.01 \mathrm{~cd}$ \\
\hline Pb $100+$ EDTA & $15.33 \pm 0.58 \mathrm{c}$ & $3.07 \pm 0.19 \mathrm{e}$ & $8.95 \pm 1.30 \mathrm{e}$ & $0.64 \pm 0.09 \mathrm{~d}$ & $8.51 \pm 0.38 \mathrm{e}$ & $0.71 \pm 0.03 \mathrm{e}$ & $0.07 \pm 0.01 \mathrm{c}$ & $7.14 \pm 0.91 \mathrm{~d}$ & $0.68 \pm 0.07 \mathrm{~d}$ & $0.07 \pm 0.02 \mathrm{e}$ \\
\hline
\end{tabular}

Table 1. Physiological parameters of $P$. hybrida L. with reference to HMs and EDTA exposure. In each column of metal treatment statistical comparison was done with the same control and control +EDTA. Data was presented in means $(\mathrm{n}=3 \pm \mathrm{SD}){ }^{\mathrm{a}}$ Alphabets followed by number $(1=\mathrm{Cd}, 2=\mathrm{Cr}, 3=\mathrm{Cu}, 4=\mathrm{Ni}$, and $5=\mathrm{Pb})$ represents statistical differences of control to each of the HMs. Significantly highest mean was "a" column wise followed by later alphabets for lower means. Similar small letter in same column within same metal treatment of experiment are non-significant. * Represents statistically highest reduction among all metal treatments and controls.

of phytoremediation technology and identification of tolerance limit. Petunia hybrida L. is a very commonly grown plant for ornamental purposes around the world and has also been used as a model plant in scientific research work, with well-established agronomic practices for the cultivation ${ }^{11}$. We performed the experiments with Petunia hybrida L. in hydroponics and exposed them to $\mathrm{Cd}, \mathrm{Cu}, \mathrm{Cr}, \mathrm{Ni}$, and $\mathrm{Pb}$. These $\mathrm{HMs}$ were selected for the study, as they are listed among the priority pollutants under the clean water act and are known for their deleterious impacts on environment, notably plants and animals (including human) ${ }^{3,5}$. Advantage of performing experiment in hydroponic system is that by this way it is possible to identify the actual potential of a plant without the influence of soil and associated microbial population, and to know how these plants will perform with the increased metal bioavailability and mobility. It is well established that Ethylenediaminetetraacetic acid (EDTA) enhanced translocation of HMs in root and shoot ${ }^{12}$, there is no evidence whether the use of this chelating agent can promote or demote the growth of Petunia hybrida L., and hence here in this work we investigated the effect of selected $\mathrm{HMs}(\mathrm{Cd}, \mathrm{Cu}, \mathrm{Cr}, \mathrm{Ni}$, and $\mathrm{Pb})$ on the plant physiology, biochemical characteristic, enzyme activity and metal uptake potential, with and without EDTA.

\section{Results}

Growth response. The exposure to selected HMs resulted in reduction and decrease in plant physiological parameters of $P$. hybrida. Studied parameters included total leaves per plant, root and shoot length, leaf area, fresh and dried weights of leaves, root and shoot (Table 1). The use of EDTA in Hoagland's nutrient solution resulted in significant reduction of studied physiological parameters, when compared with control, and EDTA along with each selected HMs induced significant higher reduction of physiological parameters, in contrast to treatments in which only plants were exposed to HMs without EDTA. Comparing the effect of selected metal on physiological parameter, statistically significant reduction of leaf number in $\mathrm{Cu} 100 \mu \mathrm{M}+$ EDTA ( 6 leaves per plant), leaf area in both exposure concentrations of $\mathrm{Cd}, \mathrm{Cu}$ and $\mathrm{Cr}$ with EDTA (ranging between 1.34 to $0.81 \mathrm{~cm}^{2}$ ), leaf $\mathrm{FW}$ in $\mathrm{Cu} 100 \mu \mathrm{M}+\operatorname{EDTA}(0.63 \mathrm{~g})$, leaf DW in Cd $100 \mu \mathrm{M}+$ EDTA $(0.05 \mathrm{~g})$, root length $(\mathrm{cm})$ and FWs $(\mathrm{g})$ in Cd $100 \mu \mathrm{M}(2.1$, and 0.26 , respectively), root DW in Ni $100 \mu \mathrm{M}+$ EDTA $(0.03 \mathrm{~g})$, shoot length in Cd $100 \mu \mathrm{M}+$ EDTA $(3.24 \mathrm{~cm})$, shoot FW in $\mathrm{Cd}$, and $\mathrm{Cu}$ in $100 \mu \mathrm{M}$ with EDTA $(0.21$ and $0.23 \mathrm{~g}$, respectively), and shoot DW in Cd, and $\mathrm{Cu} 100 \mu \mathrm{M}+\operatorname{EDTA}(0.3$ in both cases) was observed.

Among the studied physiological parameters, significantly high to moderate negative coefficient correlation were noted at $p=0.005$, where $\mathrm{n}=18$, between metal uptake and studied parameters, while leaf area, leaf 
a)

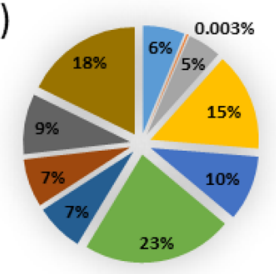

d)

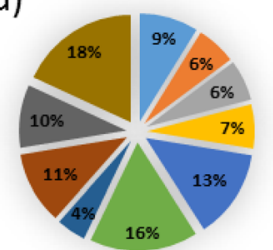

b)

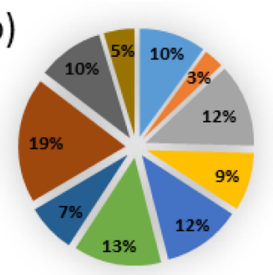

e)

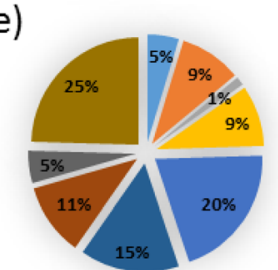

c)

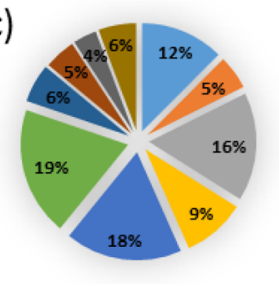

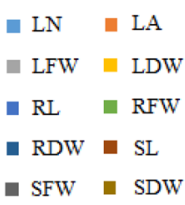

- LFW LDW

- SFW - SDW

\begin{tabular}{|c|c|c|c|c|c|}
\hline Uptake & $\begin{array}{l}\text { MLR equation for HM uptake with reference to plant physiology } \\
\text { (after min-max normalization) }\end{array}$ & $\mathrm{R}^{2}$ & F & Sig & $\mathrm{CPC}^{*}$ \\
\hline $\mathrm{Cd}$ & $\begin{array}{c}=1.06-0.659 L N+0.028 L A-0.531 L F W+1.546 L D W-1.029 R L+2.373 R F W+ \\
\quad 0.761 R D W-0.764 S L-0.955 S F W-1.865 S D W\end{array}$ & 0.990 & 68.747 & 0.0001 & a \\
\hline $\mathrm{Cr}$ & $\begin{array}{c}=1.249-1.61 L N+0.488 L A+2.007 L F W+1.41 L D W+1.917 R L-2.12 R F W- \\
\quad 1.184 R D W-3.045 S L+1.607 S F W-0.749 S D W\end{array}$ & 0.925 & 8.625 & 0.005 & $\mathrm{~b}$ \\
\hline $\mathrm{Cu}$ & $\begin{array}{c}=0.71-1.453 L N+0.6 L A-1.906 L F W+1.101 L D W+2.039 R L-2.259 R F W+ \\
\quad 0.676 R D W-0.552 S L+0.412 S F W+0.666 S D W\end{array}$ & 0.998 & 389.190 & 0.0001 & c \\
\hline $\mathrm{Ni}$ & $\begin{array}{c}=1.368-1.518 L N+1.033 L A-1.06 L F W+1.145 L D W-2.305 R L-2.794 R F W+ \\
\quad 0.764 R D W+1.869 S L-1.633 S F W+3.121 S D W\end{array}$ & 0.976 & 28.535 & 0.0001 & d \\
\hline $\mathrm{Pb}$ & $\begin{array}{c}=-0.533+1.046 L N-2.067 L A-0.29 L F W-2.051 L D W+4.536 R L-0.001 R F W+ \\
3.308 R D W+2.414 S L-1.086 S F W-5.462 S D W\end{array}$ & 0.924 & 8.512 & 0.005 & e \\
\hline
\end{tabular}

${ }^{*} \mathrm{CPC}=$ Cumulative percentage contribution

Figure 1. MLR based analysis of HMs uptake and plant physiological parameter of $P$. hydrida $\mathrm{L}$. (including $\mathrm{LN}=$ Leaf number, $\mathrm{LA}=$ Leaf area, $\mathrm{LFW}=$ Leaf fresh weight, $\mathrm{LDW}=$ Leaf dried weight, $\mathrm{RL}=$ Root length, RFW = Root fresh weight, RDW = Root dried weight, $\mathrm{SL}=$ Shoot length, $\mathrm{SFW}=$ Shoot fresh weight, SDW $=$ Shoot dried weight, while CPCs for each of the physiological parameters against HM are presented as follow (a) $\mathrm{Cd}$, (b) $\mathrm{Cr}$, (c) $\mathrm{Cu},(\mathbf{d}) \mathrm{Ni}$, and (e) $\mathrm{Pb}$.

fresh and dried weight were found negatively affected, at the $p=0.05$ where $\mathrm{n}=18$, with reference to $\mathrm{Pb}$ and $\mathrm{Ni}$. (Supplementary Table $\mathrm{S} 1$ ). The $\mathrm{R}^{2}$ value for each of the selected metal uptake model was higher than 0.9 , indicating the good fit of the model (Fig. 1). In case of Cd, and Cu the CPC was highest for the root FW (23, and 19\%, respectively), shoot length in $\mathrm{Cr}(19 \%)$, while for $\mathrm{Ni}$ and $\mathrm{Pb}$ the highest $\mathrm{CPC}$ was noted for shoot dried wright (18, and $25 \%$, respectively).

Stress injury. Effects of selected HMs application on chlorophyll content (chlorophyll per $\mathrm{g}^{-1}$ of FW), including chlorophyll a (Chl a), chlorophyll b (Chl b), total chlorophyll (Chl T) and carotenoid (Car) content were presented in Fig. 2. Abrupt decline in Chl a (74.5\%), Chl b (79\%) and Chl T (76.8\%) were noted for Cd treatments, and significantly highest in all cases of $100 \mu \mathrm{M}$, when compared with control. For Car, statistically significant decline was noted for $\mathrm{Cd}$ treatment at 50 and $100 \mu \mathrm{M}$, and with $\mathrm{Cu}$ at $100 \mu \mathrm{M}+\mathrm{EDTA}(\sim 67 \%)$, in comparison to control. The addition of EDTA significantly improved plant growth, in the case of $\mathrm{Cd}$. While, no variation for $\mathrm{Cr}$ and $\mathrm{Ni}$ was noted. Significantly highest lipid peroxidation ( $\mu \mathrm{M}$ of MDA g ${ }^{-1}$ of FW), EL, and $\mathrm{H}_{2} \mathrm{O}_{2}$ were noted for $100 \mu \mathrm{MCd}$ treatment with EDTA (Fig. 3). In case of $\mathrm{Cr}$ and Pb, highest MDA contents were noted at $100 \mu \mathrm{M}$ metal concentration ( 0.013 and 0.011 , respectively), while for $\mathrm{Cd}, \mathrm{Cu}$ and $\mathrm{Ni}, 100 \mu \mathrm{M}$ metal treatment with EDTA resulted in highest MDA contents $\left(0.025,0.018\right.$ and $0.012 \mu \mathrm{Mg}^{-1} \mathrm{FW}$, respectively). The highest percentages for EL were noted for $\mathrm{Cd}, \mathrm{Cr}, \mathrm{Cu}$ and $\mathrm{Ni}$, at $100 \mu \mathrm{M}$ metal treatments with EDTA, with the following trend, Cd $(97.7 \%)>\mathrm{Ni}(86.7 \%)>\mathrm{Cr}(74.7 \%)>\mathrm{Cu}(74 \%)$. In case of $\mathrm{Pb}$ statistically significantly higher EL was recorded for $100 \mu \mathrm{M} \mathrm{Pb}$ concentration (72\%), as compared to control. The $\mathrm{H}_{2} \mathrm{O}_{2}$ contents for $\mathrm{Cd}$ and $\mathrm{Cu}$ were highest, and for $\mathrm{Cd}$ and $\mathrm{Pb}$, were also higher with $100 \mu \mathrm{M}$ metal treatments with EDTA, while in case of Ni at $100 \mu \mathrm{M}$ metal treatments, in both conditions with and without EDTA, were resulted significantly highest $\mathrm{H}_{2} \mathrm{O}_{2}$ content. Supplementary Table S2, represented the coefficient correlation between selected HMs and stress indicator. MDA content, EL and $\mathrm{H}_{2} \mathrm{O}_{2}$ contents were found strongly positively correlated, while were found negatively correlated for $\mathrm{Chl} \mathrm{a,} \mathrm{Chl} \mathrm{b,} \mathrm{Chl} \mathrm{T} \mathrm{and} \mathrm{Car} \mathrm{with} \mathrm{metal} \mathrm{uptake.} \mathrm{The} \mathrm{coefficient} \mathrm{correlations} \mathrm{were} \mathrm{high} \mathrm{to} \mathrm{moderate} \mathrm{between}$ each case. MLR equations and cumulative percentage contributions were presented for metal uptake and studied stress indicators (Fig. 4). MDA contents was found to have highest percentage contribution (39, 37, 33, and 27\%, respectively) for $\mathrm{Ni}, \mathrm{Cd}, \mathrm{Pb}$ and $\mathrm{Cr}$. While, for $\mathrm{Cu}$ the $\mathrm{H}_{2} \mathrm{O}_{2}$ content resulted in highest $\mathrm{CPC}$ (39\%). The high MLR coefficients $\left(\mathrm{R}^{2}\right)$ were observed for each metal ranging from 0.873 to 0.925 . 

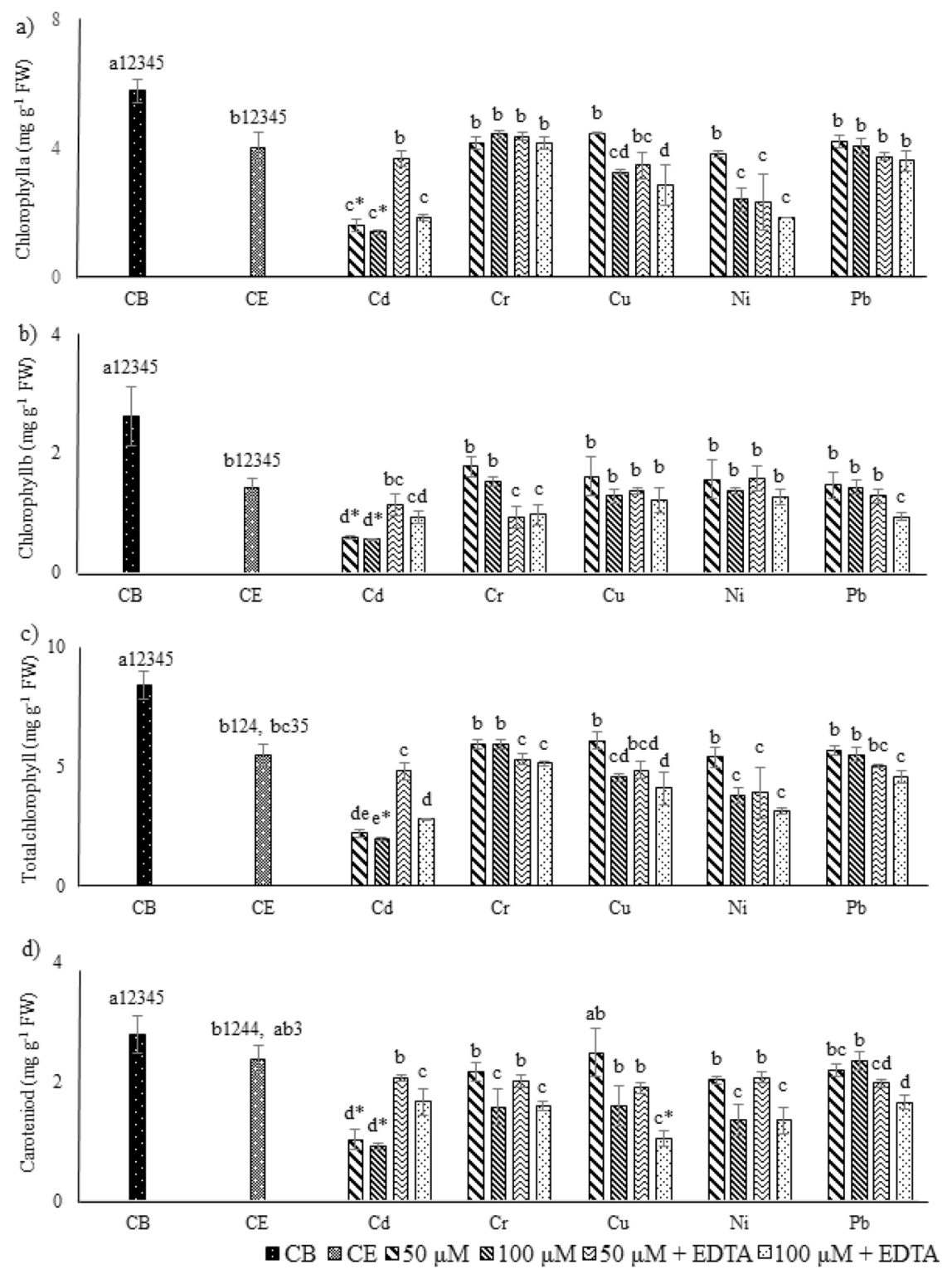

Figure 2. Effects of HMs and EDTA co-application on Chlorophyll and carotenoid contents of $P$. hydrida L. (a) Chlorophyll a, (b) Chlorophyll b, (c) Total chlorophyll, and (d) Carotenoid content. Statistical comparison is presented in different series of bars $(50=50 \mu \mathrm{M}$ of $\mathrm{HM}, 100=100 \mu \mathrm{M}$ of $\mathrm{HM}, 50+\mathrm{ETDA}=50 \mu \mathrm{M}+2.5 \mathrm{mM}$ $\mathrm{EDTA}, 100+\mathrm{EDTA}=100 \mu \mathrm{M}+2.5 \mathrm{mM}$ EDTA) by using the same control (CB) and control $+\mathrm{EDTA}(\mathrm{CE})$. Data are in means $(n=3 \pm S D)$. Alphabets represent statistical differences, number followed by alphabets in $C B$ and $\mathrm{CE}$ represents difference with metals $(1=\mathrm{Cd}, 2=\mathrm{Cr}, 3=\mathrm{Cu}, 4=\mathrm{Ni}$, and $5=\mathrm{Pb})$, significantly highest mean was "a" in each series of bars followed by later alphabets for lower means. *Represents significantly highest reduction.

Antioxidant enzyme activity. The activities of CAT, POX, GST, APX, and SOD content in leaves of $P$. hybrida exposed to $\mathrm{Cd}, \mathrm{Cr}, \mathrm{Cu}, \mathrm{Ni}$ and $\mathrm{Pb}$ with or without EDTA were presented in Table 2. Enzyme activities (including CAT, POX, GST, APX and SOD) increased with increasing the concentrations of selected HMs from 0 to 50 and $100 \mu \mathrm{M}$. The addition of EDTA with HMs, resulted in statistically significant amplification in all enzyme activities of $P$. hybrida, except in the case of POX activity, where highest value was noted for $\mathrm{Cr} 100 \mu \mathrm{M}\left(0.88 \mathrm{U} \mathrm{g}^{-1}\right.$ of FW), and reduction in POX activity was noted with the addition of EDTA along with Cr at 50 and $100 \mu \mathrm{M}(0.31$ and $0.41 \mathrm{U} \mathrm{g}^{-1}$ of $\left.\mathrm{FW}\right)$. While, in the case of SOD statistically insignificant variations were noted with or without EDTA at both concentration of 50 and $100 \mu \mathrm{M}$ with $\mathrm{Pb}$. Upon paralleling the effect on enzyme activities among selected metals, statistically significant increase in CAT in Cd $100 \mu \mathrm{M}+\mathrm{EDTA}\left(1.13 \mathrm{U} \mathrm{g}^{-1}\right.$ of FW), POX and GST in $\mathrm{Cu} 100 \mu \mathrm{M}+$ EDTA $\left(0.88 \mathrm{U} \mathrm{g}^{-1}\right.$ of FW and $\left.0.62 \mu \mathrm{M} \mathrm{min}^{-1} \mathrm{~g}^{-1} \mathrm{FW}\right)$, APX in treatments of Cd and $\mathrm{Ni}$ at $100 \mu \mathrm{M}$ with EDTA (0.38 and $0.37 \mathrm{U} \mathrm{g}^{-1}$ of FW), and SOD in Cd $100 \mu \mathrm{M}+$ EDTA (3.19 $\mathrm{U} \mathrm{g}^{-1}$ of FW) were observed. Correlation between enzyme activities and heavy metal exposure was presented in Supplementary Table S3. Among selected enzymes Cd exposure showed strong positive correlation in case of SOD (0.746), while for CAT, POX, GST moderate positive correlations $(0.640,0.613$ and 0.633$)$ were noted at the $p=0.005$, when $\mathrm{n}=18$, with 

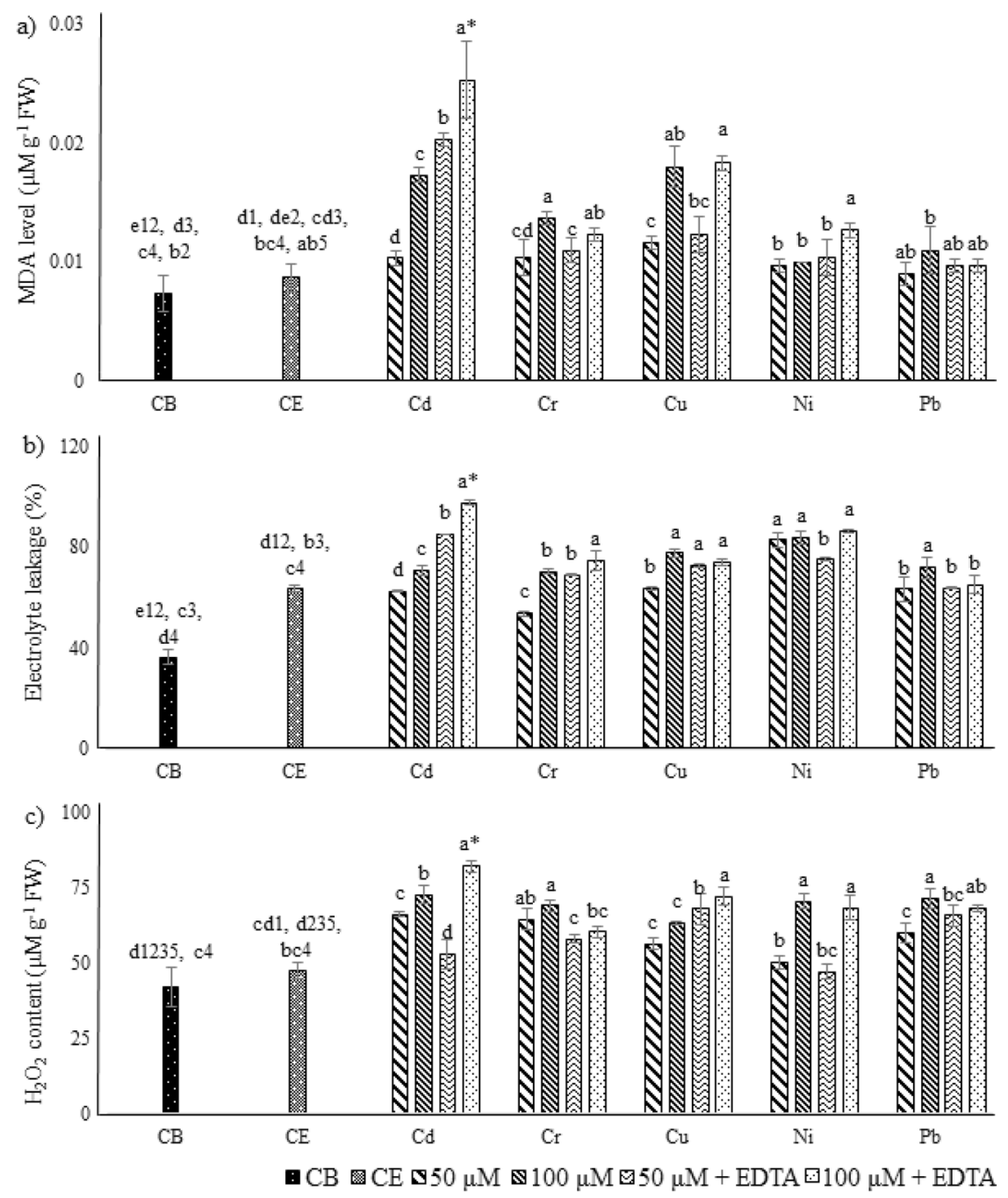

Figure 3. Effects of HMs and EDTA co-application on (a) MDA level. (b) Electrolyte content, and (c) $\mathrm{H}_{2} \mathrm{O}_{2}$ content of $P$. hydrida L. Statistical comparison is presented in different series of bars $(50=50 \mu \mathrm{M}$ of $\mathrm{HM}$, $100=100 \mu \mathrm{M}$ of $\mathrm{HM}, 50+\mathrm{ETDA}=50 \mu \mathrm{M}+2.5 \mathrm{mM}$ EDTA, $100+\mathrm{EDTA}=100 \mu \mathrm{M}+2.5 \mathrm{mM}$ EDTA $)$ by using the same control $(\mathrm{CB})$ and control + EDTA $(\mathrm{CE})$. Data are in means $(\mathrm{n}=3 \pm \mathrm{SD})$. Alphabets represent statistical differences, number followed by alphabets in $\mathrm{CB}$ and $\mathrm{CE}$ represents difference with metals $(1=\mathrm{Cd}, 2=\mathrm{Cr}$, $3=\mathrm{Cu}, 4=\mathrm{Ni}$, and $5=\mathrm{Pb}$ ), significantly highest mean was "a" in each series of bars followed by later alphabets for lower means. *Represents significantly highest reduction.

insignificant correlation for APX. With Cr, strong positive correlations were identified for CAT, GST and APX $(0.889,0.812$, and 0.921 , respectively), while for POX and SOD activity moderate correlations were observed (0.69 and 0.59 , receptively) at the $p=0.005$ when $\mathrm{n}=18$. Exposure of $P$. hydrida to copper displayed strong positive correlations with CAT, APX, and SOD $(0.733,0.091$, and 0.746 , respectively), moderate positive with GST $(0.602)$ at the $p=0.005$ when $\mathrm{n}=18$, while weak positive with $\operatorname{POX}(0.453)$ at the $p=0.05$ when $\mathrm{n}=18$. The treatment with Ni showed strong positive correlations with all enzyme activities at the $p=0.005$ where $\mathrm{n}=18$. Furthermore, $\mathrm{Pb}$ exposure found to have strong positive correlations with CAT and POX (0.810, and 0.728, respectively), while moderate positive correlation with GST (0.595) and SOD (0.668) at the $p=0.005$ when $\mathrm{n}=18$. APX was also found to have moderate positive correlation with $\mathrm{Pb}$ exposure $(0.530$ at the $p=0.05$ when $\mathrm{n}=18)$. Figure 5 represented the cumulative percentage contribution and MLR equation for each selected metal and studied enzyme activities. In case of $\mathrm{Cr}, \mathrm{Cu}, \mathrm{Ni}$ and $\mathrm{Pb}$ significantly higher MLR coefficients $\left(\mathrm{R}^{2}\right)$ were observed. While, with $\mathrm{Cd}$ the model's $\mathrm{R}^{2}$ value was found to be moderate. Highest CPC noted for uptake of Cd was with SOD (38\%), for Cr with CAT (30\%), $\mathrm{Cu}$ and Ni for APX (70 and 44\%, respectively), and for Pb with CAT and POX (27, and 27\%, respectively).

Heavy metal uptake. Heavy metal uptake by Petunia hybrida L. was dose dependent, as increase in metal concentration resulted in increased HM content with in the plant tissues (Fig. 6). The use of EDTA also exacerbated the metal content uptake. However, the pattern of compartmentalization, i.e. metal content in each of the plant compartment (root, shoot and leaf), varied. In case of $\mathrm{Cd}$, the distribution of metal was found comparatively uniform, but with the addition of EDTA higher Cd content was noted in leaf, followed by shoot and root. 
a)

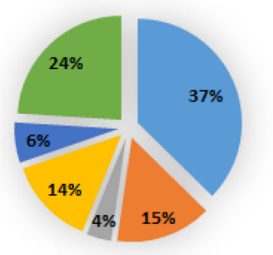

d)

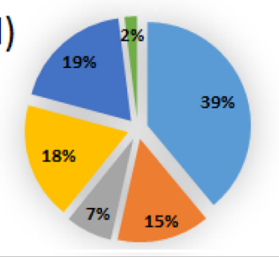

b)

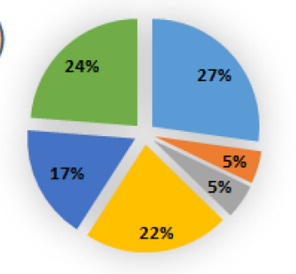

e)

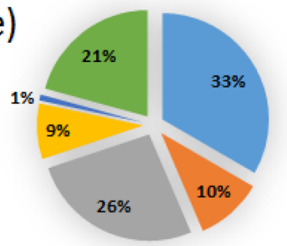

c)

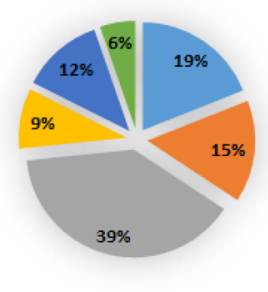

MDA

$\square \mathrm{Chla} \quad \square \mathrm{H}_{2} \mathrm{O}_{2}$

achl b $\quad$ Car

\begin{tabular}{|c|c|c|c|c|c|}
\hline Uptake & $\begin{array}{l}\text { MLR equation for HM uptake with reference to stress indicators } \\
\text { (after min-max normalization) }\end{array}$ & $\mathrm{R}^{2}$ & F & Sig & $\mathrm{CPC}^{*}$ \\
\hline $\mathrm{Cd}$ & $=0.1590+0.716 \mathrm{MDA}+0.286 \mathrm{EL}+0.074 \mathrm{H}_{2} \mathrm{O}_{2}+0.261 \mathrm{ChlA}-0.12 \mathrm{Chl} \mathrm{B}-0.46 \mathrm{Car}$ & 0.873 & 12.568 & 0.0001 & a \\
\hline $\mathrm{Cr}$ & $=0.611+1.19 \mathrm{MDA}-0.214 \mathrm{EL}-0.226 \mathrm{H}_{2} \mathrm{O}_{2}+0.954 \mathrm{Chl} \mathrm{A}-0.75 \mathrm{Chl} \mathrm{B}-1.039 \mathrm{Car}$ & 0.834 & 9.188 & 0.001 & $\mathrm{~b}$ \\
\hline $\mathrm{Cu}$ & $=-1.016+0.642 \mathrm{MDA}+0.517 \mathrm{EL}+1.323 \mathrm{H}_{2} \mathrm{O}_{2}+0.305 \mathrm{ChlA}+0.415 \mathrm{ChlB}+0.18 \mathrm{Car}$ & 0.925 & 22.578 & 0.0001 & c \\
\hline $\mathrm{Ni}$ & $=-0.086+1.251 \mathrm{MDA}+0.467 \mathrm{EL}+0.234 \mathrm{H}_{2} \mathrm{O}_{2}-0.59 \mathrm{ChlA}+0.604 \mathrm{ChlB}-0.064 \mathrm{Car}$ & 0.871 & 12.4 & 0.0001 & d \\
\hline $\mathrm{Pb}$ & $=0.221+1.408 \mathrm{MDA}-0.431 \mathrm{EL}+1.11 \mathrm{H}_{2} \mathrm{O}_{2}+0.357 \mathrm{ChlA}-0.038 \mathrm{Chl} \mathrm{B}-0.876 \mathrm{Car}$ & 0.924 & 22.278 & 0.0001 & e \\
\hline
\end{tabular}

${ }^{*} \mathrm{CPC}=$ Cumulative percentage contribution

Figure 4. MLR based analysis of HMs stress indicators of $P$. hydrida $\mathrm{L}$. (including MDA $=$ Malondialdehyde content, $\mathrm{EL}=$ Electrolyte leakage, $\mathrm{Chl} \mathrm{a}=$ Chlorophyll $\mathrm{a}, \mathrm{Chl} \mathrm{b}=$ Chlorophyll $\mathrm{b}, \mathrm{Car}=$ Carotenoid, and $\mathrm{H}_{2} \mathrm{O}_{2}=$ Hydrogen peroxide content), while CPCs for each of the stress indicating parameters against $\mathrm{HM}$ are presented as follows (a) $\mathrm{Cd}$, (b) $\mathrm{Cr}$, (c) $\mathrm{Cu}$, (d) $\mathrm{Ni}$, and (e) $\mathrm{Pb}$.

Leaf contained highest metal content, when plants were treated with $\mathrm{Cr}$, followed by a dose dependent increase in shoot, while in root the content of $\mathrm{Cr}$ was comparatively uniform with no statistical difference. Application of EDTA with $\mathrm{Cr}$ resulted in highest content of $\mathrm{Cr}$ with in the leaf, followed by root and then shoot. Copper content was found highest in root in all the treatments, interestingly with co-application of EDTA, the shoot metal content increased significantly. With $\mathrm{Ni}$ and $\mathrm{Pb}$, the metal uptake was found to be highest in leaf and is influenced by both the dose of application and addition of EDTA with metal treatments.

\section{Discussion}

Use of ornamental plant is expected to grow with the passage of time, not just because they can improve the aesthetics of the urban dwellings and medicinal advantages, but also in the field of phytoremediation, as this discipline is an ever evolving method and much attention was not given on the ornamental plants9,10,13. Therefore, it will be a good approach to investigate commonly used ornamental plants. This will not only help to identify the potential for any possible use in phytoremediation technology, but will also in the scaling the tolerance limit against HMs, assistance to maintain the vibrant aesthetics of these plants when used in urban surroundings (like roads, gardens, and walking lanes) under the expected stress of environmental contaminants spread due to anthropogenic activities (vehicular exhaust, irrigation with contaminated water, soil erosion, and even dust scattering due to pedestrian). This study was designed to understand the tolerance level and metal uptake pattern of Petunia hybrida L., when exposed to cadmium, chromium, copper, nickel and lead, with and without addition of EDTA, and to best of our knowledge no such competitive study was done. The use of EDTA for ameliorated extraction of heavy metals was well documented in already published data with other plants like Brassica napus $^{4,12}$, Brassica rapa ${ }^{14}$, Phaseolus vulgaris and Zea mays ${ }^{15}$, and Helianthus annuus ${ }^{13,16}$. The effect of addition of EDTA was also found to vary (positive or negative) among different plants ${ }^{4,13,14}$.

Effects of HMs and EDTA exposure on plant physiological status. In the present study, it was observed that addition of EDTA enhanced the HMs uptake, but enhanced metal uptake resulted in reduced plant growth. The studied physiological parameters of Petunia hybrida L. were negatively influenced by the increasing the concentration of selected HMs in the hydroponic media (Table 1 and Supplementary Table S1). The impact was further escalated, when the HMs were provided with co-application of EDTA. The negative impact of HMs was dose dependent, while for EDTA the negative impact was due to increased toxic HMs uptake and the hindrance in essential metal uptake as EDTA bind non-specially with metals, resulting in chelation of metals required by plant along with the toxic $\mathrm{HMs}^{16}$. Further the chelator mediated toxicity also reduced the plant biomass, limiting the metal uptake ${ }^{17}$, as with low biomass limited HM is expected to be translocate. It should further be noted that a higher HM concentration in plant tissue by the addition of metal chelating agent did not necessarily mean a better removal efficiency, as the change in biomass and other physiological parameter 


\begin{tabular}{|c|c|c|c|c|c|}
\hline & Catalase $^{+}$ & Guaiacol peroxidase $^{+}$ & Glutathione S-transferase $^{+}$ & Ascorbate peroxidase $^{+}$ & Superoxide dismutase $^{+}$ \\
\hline Control $^{a}$ & $0.53 \pm 0.06 \mathrm{c} 12345$ & $0.14 \pm 0.02 \mathrm{c} 15, \mathrm{~d} 234$ & $0.33 \pm 0.01 \mathrm{c} 125, \mathrm{~d} 3, \mathrm{e} 4$ & $0.03 \pm 0.00 \mathrm{c} 14, \mathrm{~d} 235$ & $1.39 \pm 0.07 \mathrm{cl} 25, \mathrm{~d} 3, \mathrm{~b} 4$ \\
\hline Control+EDTA ${ }^{\mathrm{a}}$ & $0.54 \pm 0.04 \mathrm{c} 12345$ & $0.17 \pm 0.02 \mathrm{c} 15, \mathrm{~d} 234$ & $0.41 \pm 0.02 \mathrm{~b} 1235, \mathrm{c} 4$ & $0.05 \pm 0.01 \mathrm{c} 145, \mathrm{~d} 23$ & $1.44 \pm 0.09 \mathrm{c} 125, \mathrm{~d} 3, \mathrm{~b} 4$ \\
\hline Cd 50 & $0.56 \pm 0.04 \mathrm{c}$ & $0.17 \pm 0.01 c$ & $0.34 \pm 0.01 \mathrm{c}$ & $0.05 \pm 0.00 c$ & $1.65 \pm 0.07 \mathrm{bc}$ \\
\hline $\mathrm{Cd} 100$ & $0.66 \pm 0.01 \mathrm{~b}$ & $0.49 \pm 0.03 a$ & $0.41 \pm 0.04 \mathrm{~b}$ & $0.11 \pm 0.01 \mathrm{~b}$ & $1.88 \pm 0.05 b c$ \\
\hline Cd 50+EDTA & $0.55 \pm 0.1 \mathrm{c}$ & $0.30 \pm 0.03 \mathrm{~b}$ & $0.43 \pm 0.02 b$ & $0.1 \pm 0.01 \mathrm{~b}$ & $1.94 \pm 0.03 \mathrm{~b}$ \\
\hline Cd $100+$ EDTA & $1.13 \pm 0.05 \mathrm{a}^{*}$ & $0.46 \pm 0.01 \mathrm{a}$ & $0.49 \pm 0.01 \mathrm{a}$ & $0.38 \pm 0.05 \mathrm{a}^{*}$ & $3.19 \pm 0.68 \mathrm{a}^{*}$ \\
\hline Cr 50 & $0.56 \pm 0.03 c$ & $0.41 \pm 0.06 \mathrm{~b}$ & $0.38 \pm 0.02 \mathrm{c}$ & $0.07 \pm 0.01 \mathrm{~cd}$ & $1.64 \pm 0.01 \mathrm{~b}$ \\
\hline Cr 100 & $0.60 \pm 0.02 \mathrm{c}$ & $0.5 \pm 0.06 \mathrm{a}$ & $0.42 \pm 0.06 \mathrm{~b}$ & $0.11 \pm 0.04 \mathrm{bc}$ & $1.72 \pm 0.11 \mathrm{~b}$ \\
\hline Cr50+EDTA & $0.68 \pm 0.03 \mathrm{~b}$ & $0.31 \pm 0.07 \mathrm{c}$ & $0.48 \pm 0.28 \mathrm{ab}$ & $0.13 \pm 0.02 b$ & $1.67 \pm 0.15 b$ \\
\hline Cr 100+EDTA & $0.8 \pm 0.03 \mathrm{a}$ & $0.41 \pm 0.02 \mathrm{~b}$ & $0.53 \pm 0.04 \mathrm{a}$ & $0.28 \pm 0.05 \mathrm{a}$ & $2.11 \pm 0.16 \mathrm{a}$ \\
\hline $\mathrm{Cu} 50$ & $0.57 \pm 0.01 b c$ & $0.18 \pm 0.02$ & $0.34 \pm 0.02 \mathrm{~d}$ & $0.12 \pm 0.01 \mathrm{c}$ & $1.86 \pm 0.08 \mathrm{~b}$ \\
\hline $\mathrm{Cu} 100$ & $0.75 \pm 0.05 \mathrm{a}$ & $0.45 \pm 0.05 \mathrm{~b}$ & $0.47 \pm 0.02 \mathrm{~b}$ & $0.16 \pm 0.00 \mathrm{~b}$ & $2.23 \pm 0.08 \mathrm{a}$ \\
\hline $\mathrm{Cu} 50+\mathrm{EDTA}$ & $0.62 \pm 0.06 \mathrm{~b}$ & $0.37 \pm 0.03 c$ & $0.46 \pm 0.02 \mathrm{~b}$ & $0.14 \pm 0.03 \mathrm{bc}$ & $1.63 \pm 0.10 c$ \\
\hline $\mathrm{Cu} 100+\mathrm{EDTA}$ & $0.73 \pm 0.00 \mathrm{a}$ & $0.88 \pm 0.03 a^{*}$ & $0.62 \pm 0.02 \mathrm{a}^{*}$ & $0.26 \pm 0.03 a$ & $2.01 \pm 0.20 \mathrm{~b}$ \\
\hline $\mathrm{Ni} 50$ & $0.63 \pm 0.01 \mathrm{~b}$ & $0.28 \pm 0.06 c$ & $0.37 \pm 0.03 \mathrm{~d}$ & $0.03 \pm 0.00 \mathrm{c}$ & $1.49 \pm 0.02 b$ \\
\hline Ni 100 & $0.64 \pm 0.01 \mathrm{~b}$ & $0.47 \pm 0.02 \mathrm{a}$ & $0.4 \pm 0.01 \mathrm{~cd}$ & $0.04 \pm 0.01 \mathrm{c}$ & $1.54 \pm 0.13 \mathrm{~b}$ \\
\hline Ni 50 + EDTA & $0.56 \pm 0.03 c$ & $0.26 \pm 0.03 c$ & $0.47 \pm 0.01 \mathrm{~b}$ & $0.21 \pm 0.04 \mathrm{~b}$ & $1.65 \pm 0.12 \mathrm{ab}$ \\
\hline Ni $100+$ EDTA & $0.84 \pm 0.05 \mathrm{a}$ & $0.36 \pm 0.04 \mathrm{~b}$ & $0.52 \pm 0.01 \mathrm{a}$ & $0.37 \pm 0.02 \mathrm{a}^{*}$ & $1.88 \pm 0.09 \mathrm{a}$ \\
\hline $\mathrm{Pb} 50$ & $0.55 \pm 0.02 \mathrm{c}$ & $0.15 \pm 0.02 \mathrm{c}$ & $0.34 \pm 0.01 \mathrm{c}$ & $0.04 \pm 0.01 \mathrm{c}$ & $1.56 \pm 0.34 \mathrm{ab}$ \\
\hline $\mathrm{Pb} 100$ & $0.68 \pm 0.04 \mathrm{~b}$ & $0.18 \pm 0.01 \mathrm{c}$ & $0.39 \pm 0.03 b$ & $0.04 \pm 0.00 \mathrm{c}$ & $1.79 \pm 0.21 \mathrm{a}$ \\
\hline $\mathrm{Pb} 50+\mathrm{EDTA}$ & $0.64 \pm 0.03 b$ & $0.26 \pm 0.02 \mathrm{~b}$ & $0.39 \pm 0.01 \mathrm{~b}$ & $0.05 \pm 0.01 \mathrm{~b}$ & $1.54 \pm 0.07 \mathrm{ab}$ \\
\hline $\mathrm{Pb} 100+\mathrm{EDTA}$ & $0.73 \pm 0.01 \mathrm{a}$ & $0.38 \pm 0.04 \mathrm{a}$ & $0.49 \pm 0.03 a$ & $0.07 \pm 0.00 \mathrm{a}$ & $1.80 \pm 0.17 \mathrm{a}$ \\
\hline
\end{tabular}

Table 2. Effect on enzyme activities of $P$. hybrida L. upon exposure of HMs and EDTA. In each column of metal treatment, statistical comparison was done with the same control and control + EDTA. Data was presented in enzyme unit per mg of fresh weight. Data are in means $(n=3 \pm S D) .{ }^{a}$ Alphabets followed by number $(1=C d$, $2=\mathrm{Cr}, 3=\mathrm{Cu}, 4=\mathrm{Ni}$, and $5=\mathrm{Pb}$ ) represents statistical differences of control to each of the HMs. Significantly highest mean was "a" column wise followed by later alphabets for lower means. Similar small letter in same column within same metal treatment of experiment are non-significant. *Represents statistically highest mean among all metal treatments and controls. ${ }^{+}$All enzyme activities are expressed in $\mathrm{U} \mathrm{g}^{-1} \mathrm{FW}$ of plant, while for

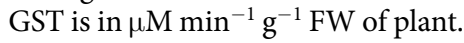

are the determining factors ${ }^{16}$. This can be better understood by identifying the contribution of each parameter towards HM uptake. Cumulative percentage contribution of each of the physiological parameters against total metal uptake (Fig. 1) was performed and checked how metal uptake is affected by reduction or increase in each of studied parameter. For Cd, and Cu the highest CPC was for the root FW (23, and 19\%, respectively), indicating that root fresh weight was significantly reduced by the uptake of these metals (Supplementary Table S1). Root fresh weight and $\mathrm{Cu}$ and $\mathrm{Cd}$ uptake were negatively co-related. Shoot length the physiological parameter is most affected. Ivanov, et al. ${ }^{18}$ performed root toxicity assay with Zea mays L. and proposed that metal toxicity was declined as follow $\mathrm{Cu} \approx \mathrm{Ti}>\mathrm{Ag}>\mathrm{Cd}>\mathrm{Hg}>\mathrm{Co}>\mathrm{Zn}>\mathrm{Pb}$, and the results were in accordance to our Petunia hybrida L. HMs exposure experimentations. When Petunia hybrida $\mathrm{L}$. plants were exposed to $\mathrm{Cr}, \mathrm{Ni}$ and $\mathrm{Pb}$ highest CPC $(19,18$, and 25\%, respectively), was noted with shoot length for $\mathrm{Cr}$ and shoot dried weights for $\mathrm{Ni}$ and $\mathrm{Pb}$, suggesting that negative influence on shoot occurred upon exposure of these HMs, and this was also evident by seeing the coefficient co-relation (Supplementary Table S1).

Plant biochemical and enzymatic status with reference to HMs and EDTA stress. Upon exposure to HMs, plants are expected to undergo stressed condition, contributing to metal uptake that leads to generation of reactive oxygen species (ROS), reduced plant turgidity, lipid peroxidation and decreased chlorophyll content ${ }^{19}$. Multiple toxic effects occur upon exposure to HMs, primarily due to formation of ROS, inhibiting cellular processes at different levels. The instability of ROS contributes; (a) damage cellular components, and (b) an important tributary for the induction of defence system ${ }^{20}$. In the present study reduced (negative correlation) in $\mathrm{Chl} \mathrm{a,} \mathrm{Chl} \mathrm{b,} \mathrm{Chl} \mathrm{T,} \mathrm{and} \mathrm{Car,} \mathrm{while} \mathrm{increased} \mathrm{(positive} \mathrm{correlation)} \mathrm{MDA}, \mathrm{H}_{2} \mathrm{O}_{2}$ contents and EL were recorded upon the stress induced by each selected $\mathrm{HM}$ at 50 and $100 \mu \mathrm{M}$ (Figs 2 and 3, Supplementary Table S2). The addition of EDTA resulted in improvement of plant pigments in case of $\mathrm{Cd}$, reduction with $\mathrm{Cr}, \mathrm{Cu}$ and $\mathrm{Ni}$, while no significant changes in $\mathrm{Pb}$. The MDA content represents damage due to lipid peroxidation, electrolyte leakage is a good indicator to check the integrity of plant cell membrane, while higher $\mathrm{H}_{2} \mathrm{O}_{2}$ content shows the production of ROS ${ }^{12,21}$. Upon exposure to HMs, and successive increase in the exposure concentrations led to increment in EL, MDA, and $\mathrm{H}_{2} \mathrm{O}_{2}$ content, while the addition of EDTA did not showed any positive or negative impact on these parameters, except for $\mathrm{Cd}$, where significantly higher $\mathrm{EL}, \mathrm{MDA}$, and $\mathrm{H}_{2} \mathrm{O}_{2}$ contents were noted. Hence, it can be said that the HM induced stress to Petunia hybrida L. was not reduced upon addition of EDTA, despite it was known for the metal chelating activities ${ }^{4,12,17}$. The effects on plant that occur due to EDTA facilitated HMs uptake vary broadly based on HM, and the plant effected ${ }^{4,12}$. The lipid peroxidation and oxidative damage due to metal uptake is detrimental, and in this work MDA content (for $\mathrm{Cd}, \mathrm{Cu}, \mathrm{Ni}$ and $\mathrm{Pb}$ ) and $\mathrm{H}_{2} \mathrm{O}_{2}$ (for $\mathrm{Cu}$ ) 
a)

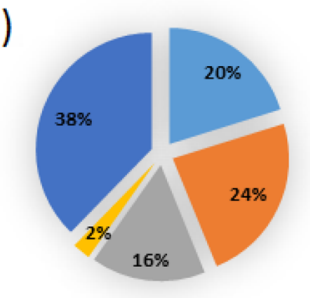

d)

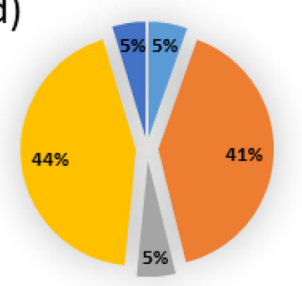

b)

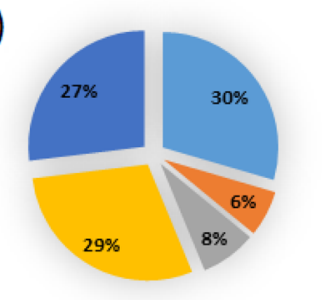

e)

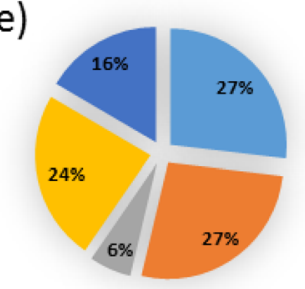

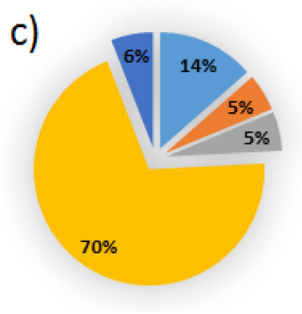

- $\mathrm{CAT} \square \mathrm{POX}$

$\square \mathrm{GST}=\mathrm{APX}$

$\square \mathrm{SOD}$

\begin{tabular}{llllll}
\hline Uptake & $\begin{array}{c}\text { MLR equation for HM uptake with reference to enzyme activity } \\
\text { (after min-max normalization) }\end{array}$ & $\mathrm{R}^{2}$ & $\mathrm{~F}$ & Sig & CPC* \\
\hline $\mathrm{Cd}$ & $=0.036-0.682 \mathrm{Cat}+0.801$ Pox +0.54 Gst $-0.085 \mathrm{Apx}+1.276 \mathrm{Sod}$ & 0.653 & 4.522 & 0.015 & $\mathrm{a}$ \\
$\mathrm{Cr}$ & $=-0.204+1.001 \mathrm{Cat}+0.217$ Pox $+0.265 \mathrm{Gst}+0.992 \mathrm{Apx}+0.912 \mathrm{Sod}$ & 0.968 & 72.831 & 0.0001 & $\mathrm{~b}$ \\
$\mathrm{Cu}$ & $=-0.06-0.67 \mathrm{Cat}+0.258$ Pox $+0.27 \mathrm{Gst}+3.463 \mathrm{Apx}+0.292 \mathrm{Sod}$ & 0.918 & 26.954 & 0.0001 & $\mathrm{c}$ \\
$\mathrm{Ni}$ & $=0.021-0.214 \mathrm{Cat}+1.614$ Pox $-0.214 \mathrm{Gst}+1.734 \mathrm{Apx}+0.184 \mathrm{Sod}$ & 0.877 & 17.171 & 0.0001 & $\mathrm{~d}$ \\
$\mathrm{~Pb}$ & $=-0.102+1.481 \mathrm{Cat}+1.48$ Pox $-0.326 \mathrm{Gst}+1.313 \mathrm{Apx}+0.913 \mathrm{Sod}$ & 0.812 & 10.371 & 0.0001 & $\mathrm{e}$ \\
\hline${ }^{*} \mathrm{CPC}=\mathrm{Cum}$
\end{tabular}

Figure 5. MLR based analysis of HMs effect on enzyme activity of $P$. hydrida L. (including CAT = Catalase, $\mathrm{POX}=$ Guaiacol peroxidase, $\mathrm{APX}=$ Ascorbate peroxidase, GST $=$ Glutathione-s-transferase, and $\mathrm{SOD}=$ Superoxide Dismutase, while CPCs for each of the enzyme activity profile against HM are presented as follows (a) Cd, (b) $\mathrm{Cr},(\mathbf{c}) \mathrm{Cu},(\mathbf{d}) \mathrm{Ni}$, and (e) $\mathrm{Pb}$.

were found to have highest CPC, for metal uptake model. It is inferred that upon exposure to HMs, the growth of Petunia hybrida L. plant was decrease due to ROS formation and lipid damage due to peroxidation. If there are no other options for the irrigation of Petunia hybrida L. except with HMs contaminated water, appropriate measures should be taken. These options include soil conditioners (individually or in combination) like, biochar, biosolids, compost, organic acids, and plant growth promoting bacterial amendments, as they have proven to reduce the toxic impacts of HMs on plants, which were not found achievable by using synthetic chelator like EDTA ${ }^{17,22,23}$, and in the current investigation as well.

The stress due to oxidative damage, induced by HMs uptake, is tackled plants with the help of defence mechanisms against oxidants. One of these mechanisms, is the use of antioxidant enzyme arsenal, including CAT, POX, GST, APX, and SOD regulating the concentration of stressors, cellular superoxide $\left(\mathrm{O}^{2-}\right)$ and hydrogen peroxide $\left(\mathrm{H}_{2} \mathrm{O}_{2}\right)$, which upon uptake of heavy metals limit the production of $\mathrm{OH}$ radicals ${ }^{4}$. Different heavy metal effect the plants by versatile ways. As discussed earlier, some directly influence production of ROS, while others interfere with antioxidant defence mechanism ${ }^{24}$, hence a different enzymatic profile against each metal should be expected. In current study, exposure of Petunia hybrida L. to the selected HMs resulted in significantly higher antioxidant enzyme activity, which was enhanced with the increasing concentrations of HMs, and co-addition of EDTA along with HMs (Table 2). Similar findings were reported by other studies ${ }^{4,12}$. Moderate to high positive correlations were noted between all enzyme activities against selected HMs, except for APX with Cd (Supplementary Table S3). The increase in enzyme activates indicated stress induced by the HMs, as there were no significant variations in enzyme activities among the controls (with and without EDTA) ${ }^{17}$. Specific responses of anti-oxidant enzymes against a particular HM play an important role in metal toxicity using cellular defence strategy ${ }^{25,26}$. In this study, similar pattern was observed (Fig. 5) that the enzymatic profiles of P. hybrida L. for each of the HMs were different. A different mix of antioxidant enzyme CPC was noted for each $\mathrm{HM}$, except in case of $\mathrm{Cu}$, where APX activity was found having a very high CPC (70\%). In another study, Wang, et al..$^{27}$ found the same pattern of enzyme activity. They suggested that higher accumulation of HM (Cd) in non-accumulator ornamental plants, including African marigold (Tagetes erecta), scarlet sage (Salvia splendens) and sweet hibiscus (Abelmoschus manihot), resulted in such an effect.

Heavy metal uptake and compartmentalization by $P$. hybrida $L$. The HM uptake was found to be dose dependent, and further enhanced by the addition of EDTA in the studied three compartments of $P$. hybrida L., comparable results were noted by Chen and Cutright ${ }^{3}$ and Kanwal, et al. ${ }^{4}$, while the HMs compartmentalization with in P. hybrida L. was found to vary for each of HMs (Fig. 6). With $\mathrm{Cr}$, Ni, and Pb, significantly higher compartmentalization occurred in P. hybrida L. leaf. Similar outcome was achieved with Cd, but the distribution of Cd was comparatively homogenous than the other three. This represented that translocate HMs to above 


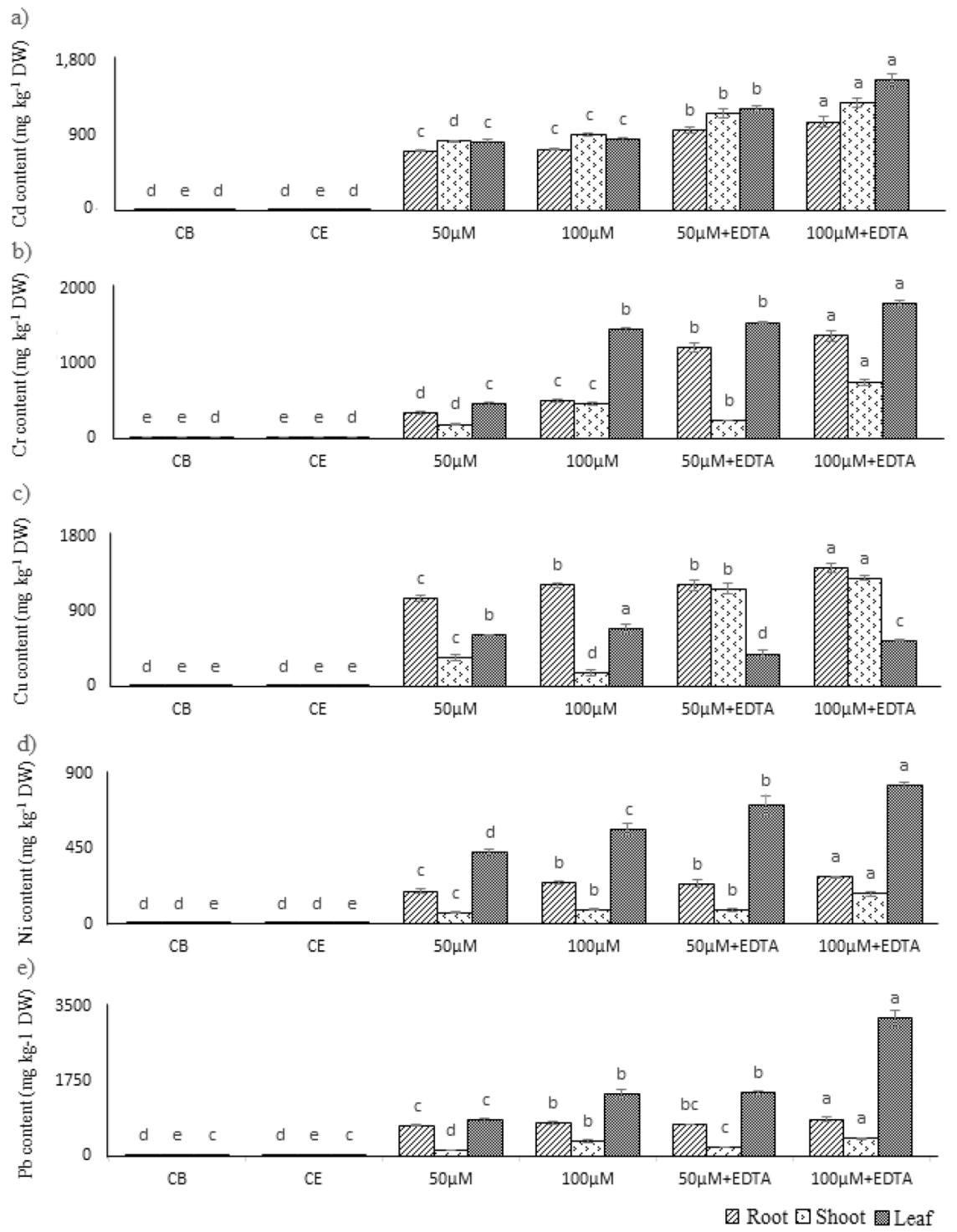

Figure 6. Uptake and compartmentalization of HMs in Petunia hybrida L. Statistical comparison is presented in different series of bars (Root, shoot, and leaf of $\mathrm{CB}, \mathrm{CE}$ with (a) Cd, (b) $\mathrm{Cr}$, (c) $\mathrm{Cu},(\mathbf{d}) \mathrm{Ni}$, and (e) Pb). Data are in means $(n=3 \pm S D)$. Alphabets represents statistical differences; significantly highest mean is " $a$ " in each bar series followed by later alphabets for lower means.

ground parts $P$. hybrida L. can lead to reduced plant vigour and aesthetics, as observed in this work that enhanced HM uptake occurred with facilitation of EDTA but with negative impacts on plant growth. For Cu, significantly higher levels were noted in roots, when P. hybrida L. was exposed to Cu stress, which increased with increasing the $\mathrm{Cu}$ in root and concentration in the external solution. Upon addition of EDTA the levels of Cu were increased in roots as well as in stem. This was due to formation of stable $\mathrm{Cu}$-EDTA complex that are transported into shoot, and higher concentration end up there as compared to the treatment with no EDTA addition and Cu stress ${ }^{28}$. Other explanation to this variable metal compartmentalization was due to differential expression of proteins responsible for metal transporting with in different part of plant. These protein families included copper transporters $(\mathrm{CTR} \text { or COPT) })^{29}$, Cation Diffusion Facilitator $(\mathrm{CDF})^{30}$, ZRT/IRT-like Protein (ZIP) ${ }^{31}$, Cation Exchanger $(\mathrm{CAX})^{32}$, Natural Resistance-Associated Macrophage Protein (NRAMP) ${ }^{30}$, and Heavy Metal ATPase (HMA) $)^{33}$.

\section{Conclusion}

The hydroponics system can provide an exact picture of the plant tolerance level for heavy metals due to non-interference of soil properties, micro/macro organisms and presence of other contaminating agents. We conclude that $P$. hybrida $\mathrm{L}$. accumulated elevated levels of $\mathrm{Cu}, \mathrm{Cd}, \mathrm{Ni}$ and $\mathrm{Pb}$ in above ground parts, but this led to reduction in plant's aesthetics, and reduced plant vigour. $P$. hybrida L. reduced Cu mobility to aerial plant parts and maintained higher concentration in the roots. The enzyme activates were increased, and this effect was dose dependent of HM concentrations while physiological and other biochemical parameters were influenced negatively by HMs uptake. The presence of chelating agent i.e. EDTA showed deleterious effects on plant health due 
to increased metal uptake, leading to physiological and biochemical stress on P. hybrida. To use P. hybrida L. in phytoremediation, the phytoextraction is not a good option. The use of $P$. hybrida L. with an appropriate combination of soil conditioners and plant growth promoting bacteria for other phytoremediation techniques, like phytostabilization is an unexplored area of research and may be feasible. Further, it is also important to investigate other ornamental plants, to know their metals/contaminants tolerance potential. Flowering plant belonging to Catharanthus, Celosia, Cosmos, Dahlia, Mirabilis, and Nicotiana genus are the good candidates for investigation due to wide cultivation, established agronomic practices, and higher biomass.

\section{Materials and Methods}

Plant material, experimental conditions and harvesting. Seeds of Petunia hybrida L. were sown in pots containing 3:1 mixture of soil to sand, and watered (when needed) with half strength Hoagland's nutrient solution ( $\mathrm{pH}$ 5.6) with the help of spray. Composition of full strength Hoagland's nutrient solution was: $5 \mathrm{mM}$ $\mathrm{KNO}_{3}, 5 \mathrm{mM} \mathrm{Ca}\left(\mathrm{NO}_{3}\right)_{2} .4 \mathrm{H}_{2} \mathrm{O}, 0.06 \mu \mathrm{M} \mathrm{Fe}(\mathrm{Na}) \mathrm{EDTA}, 2 \mathrm{mM} \mathrm{MgSO}_{4} .7 \mathrm{H}_{2} \mathrm{O}, 1 \mathrm{mM} \mathrm{NH}_{4} \mathrm{NO}_{3}, 46 \mu \mathrm{M} \mathrm{H}_{3} \mathrm{BO}_{3}, 9 \mu \mathrm{M}$ $\mathrm{MnCl}_{2} .4 \mathrm{H}_{2} \mathrm{O}, 0.76 \mathrm{mM} \mathrm{ZnSO}_{4} .7 \mathrm{H}_{2} \mathrm{O}, 0.204 \mathrm{mM} \mathrm{CuSO}_{4} .5 \mathrm{H}_{2} \mathrm{O}, 0.450 \mathrm{mM} \mathrm{Na} \mathrm{MoO}_{4} .2 \mathrm{H}_{2} \mathrm{O}, 0.5 \mathrm{mM} \mathrm{KH}_{2} \mathrm{PO}_{4}, \mathrm{pH}^{\circ}$ 5.6 (maintained with $1 \mathrm{M} \mathrm{KOH}$ or $\mathrm{H}_{2} \mathrm{SO}_{4}$ ). Pots were kept in dark till the seeds started to germinate, at $30 \pm 1^{\circ} \mathrm{C}$ in the day time and $24 \pm 1^{\circ} \mathrm{C}$ at night with a photoperiod of $16: 8$ (day:night), similar condition were maintained throughout the experiment. Upon seed germination, seedlings were transferred to wire house and after two weeks, equal sized uniform seedlings were carefully wrapped with filter wool between root and shoot, were held on thermophore sheet and were transferred to plastic containers containing full strength Hoagland's nutrient solution ( $\mathrm{pH}$ 5.6), lined with polythene sheet. The plants were acclimatized for 2 weeks, along with refreshing of Hoagland's nutrient media and polythene sheet lining weekly, to prevent media contamination and depletion of nutrients.

After the acclimation, Petunia hybrida L. plants were treated for three weeks with HMs and EDTA as T1: Blank Control, T2: EDTA control $(2.5 \mathrm{mM})$, T3: HM $(50 \mu \mathrm{M})$, T4: HM $(100 \mu \mathrm{M})$, T5: HM $(50 \mu \mathrm{M})+$ EDTA $(2.5 \mathrm{mM})$, and T6: HM $(100 \mu \mathrm{M})+$ EDTA $(2.5 \mathrm{mM})$. It is to be noted that all treatments were conducted in biological triplicates, T3, T4, T5, and T6 were different for each HM. Salts used for making representative HMs stocks were, cadmium chloride dihydrate $\left(\mathrm{CdCl}_{2} \cdot 2 \mathrm{H}_{2} \mathrm{O}\right)$ for $\mathrm{Cd}$, chromium nitrate $\left(\mathrm{Cr}\left(\mathrm{NO}_{3}\right)_{2}\right)$ for $\mathrm{Cr}$, copper sulphate pentahydrate $\left(\mathrm{CuSO}_{4} \cdot 5 \mathrm{H}_{2} \mathrm{O}\right)$ for $\mathrm{Cu}$, nickel chloride $\left(\mathrm{NiCl}_{2}\right)$ for $\mathrm{Ni}$, and lead nitrate $\left(\mathrm{Pb}\left(\mathrm{NO}_{3}\right)_{2}\right)$ for Pb. After 3 weeks, plants were harvested, roots surface were washed with distilled water, and were used for plant physiological and metal uptake analysis. Samples for biochemical analysis were stored at $-80{ }^{\circ} \mathrm{C}$ (for enzyme activities only) to avoid any disturbance in the activity. Each analysis was performed in biological triplicates.

Plant physiological parameters. Plant physiological parameters, including plant height, root length, total number of leaf per plant, fresh and dried weight (FW and DW) of root, shoot and leaves were recorded using standard method as done by Arshad, et al. ${ }^{34}$ and Habiba, et al. ${ }^{12}$. Leaf area was calculated using ImageJ software ${ }^{35}$. Samples were dried at $60^{\circ} \mathrm{C}$ till the constant weight and dried samples were used for acid digestion and then for atomic absorption spectrometry (AAS), with the help of Perkin Elmer, AAS-700, analysis for metal comparison in different plant compartments.

Plant biochemical characters. Among plant biochemical characters of plant, stress injury and antioxidant enzyme activities were noted. For stress injury chlorophyll $a, b$, total chlorophyll and carotenoid content were quantified by using method described by Arnon ${ }^{36}$ and values were expressed in mg of chlorophyll $\mathrm{g}^{-1}$ of FW. Lipid peroxidation was noted in terms of malondialdehyde (MDA) by method adopted by Venkatachalam, et al. ${ }^{37}$, and was expressed in $\mu \mathrm{M}$ of MDA g ${ }^{-1}$ of FW. Electrolyte leakage (EL) was determined by the method as describe by Nishiyama, et al. ${ }^{38}$ and was expressed in percentage. $\mathrm{H}_{2} \mathrm{O}_{2}$ contents were determined according to Habiba, et al. ${ }^{12}$. Absorbance was taken at $410 \mathrm{~nm}$ and extinction coefficient of $0.28 \mu \mathrm{M}^{-1} \mathrm{~cm}^{-1}$ was used for calculating $\mathrm{H}_{2} \mathrm{O}_{2}$ contents. The values were expressed in $\mu \mathrm{M}$ of $\mathrm{H}_{2} \mathrm{O}_{2} \mathrm{~g}^{-1}$ of FW. Quantification of plant enzyme and $\mathrm{H}_{2} \mathrm{O}_{2}$ content was done by preparation of plant extract. It was prepared using $100 \mathrm{mg}$ of leaf's tissue, homogenised with the help of pre-chilled mortar and pestle in $1 \mathrm{ml}$ of potassium phosphate buffer $(50 \mathrm{mM}, \mathrm{pH} 7.4$ containing $0.5 \mathrm{mM}$ EDTA). Resulted extracts were collected in $2 \mathrm{ml}$ tube and were centrifuged at $10000 \mathrm{~g}$ for $15 \mathrm{~min}$ at $4^{\circ} \mathrm{C}$. After centrifugation, supernatant was carefully collected in $1.5 \mathrm{ml}$ tube and was used and stored at $4{ }^{\circ} \mathrm{C}$ to prevent the deterioration ${ }^{37}$. Superoxide dismutase (SOD) activity was assayed by measuring its ability to inhibit the photochemical reduction of NBT using the method of Dhindsa, et al..$^{39}$, by noting the absorbance at $560 \mathrm{~nm}$ of the reaction mixture. One unit of SOD activity was determined as the quantity of enzyme that induced $50 \%$ prohibition of photochemical reduction of the NBT. Catalase (CAT) activity was assayed by measuring the rate of disappearance of $\mathrm{H}_{2} \mathrm{O}_{2}$ in reaction mixture using the method of Maehly ${ }^{40}$. The decrease in $\mathrm{H}_{2} \mathrm{O}_{2}$ was followed as a decline in absorbance at $240 \mathrm{~nm}$ after $1 \mathrm{~min}\left(\varepsilon=39.4 \mathrm{mM}^{-1} \mathrm{~cm}^{-1}\right)$. Ascorbate peroxidase (APX) activity was determined according to the method of Chen and Asada ${ }^{41}$, with minor modification. The oxidation of ascorbate was followed by the decrease in the absorbance at $240 \mathrm{~nm}\left(\varepsilon=2.8 \mathrm{mM}^{-1} \mathrm{~cm}^{-1}\right)$. Guaiacol peroxidase (POX) activity was determined according to Upadhyaya, et al. ${ }^{42}$, and the activity was computed using the extinction coefficient of $26.6 \mathrm{mM}^{-1} \mathrm{~cm}^{-1}$. Glutation-s-Transferase (GST) activity was assayed spectrophotometrically by measuring change of $\mathrm{A}_{340}{ }^{43}$. Reactions were initiated by the addition of 1-chloro-2,4-dinitrobenzene (CDNB), and $A_{340}$ was monitored for $120 \mathrm{~s}$ in model of time-driver and values were computed using extinction coefficient of CDNB-glutathione conjugate $\left(\varepsilon=9.6 \mathrm{mM}^{-1} \mathrm{~cm}^{-1}\right)$. Values are expressed in Units $\mathrm{g}^{-1}$ of $\mathrm{FW}$ of sample for all enzyme activities, except for GST which was expressed in $\mu \mathrm{M} \mathrm{min} \mathrm{m}^{-1} \mathrm{~g}^{-1}$ of FW.

Statistical analysis. One-way ANVOA between individual metal treatment and among all metals was performed using SPSS, followed by Duncan's multiple range test on each studied parameter. To find the correlation between metal uptake and studied parameters, Pearson's correlation analysis was conducted, after testing the 
normality of data using the Shapiro-Wilk normality test. Further to find the relation of studied parameters with cumulative metal uptake stepwise multiple linear regressions (MLR) was employed. Data was min-max normalized prior to MLR, for the prevention of large numeric ranges dominating those with small numeric range, to reduce the potential bias into the data values exactly. In this normalization method, the recorded case value is subtracted with the minimum value of recorded in that case from each value of the attribute and followed by dividing the difference by the range of the studied case.

$$
Z=\frac{x-\min (x)}{\max (x)-\min (x)}
$$

Where, $Z$ is the normalized observed value of $\mathrm{x}$, min and max are the minimum and maximum values in $\mathrm{x}$ given its range. The normalized values lay in the range $[0,1]$. The advantage of this normalization is that it preserves all relationships of the data. Using MLR, multivariate model was constructed for metal uptake, the dependent variable Y, based on consciously selected studied variables (X). MLR coefficient $\left(R^{2}\right)$ showing highest value is ideal for the best equation. Based on these assumptions we can say:

$$
Y=b_{0}+b_{1} X_{1}+b_{2} X_{2}+\ldots+b_{n t h} X_{n t h}
$$

Where, $Y$ is the metal uptake (dependent variable), $X_{1}, X_{2}, \ldots, X_{n}$ are descriptive studied variables for plant physiology, enzyme activity, biochemical characteristic, and induced stress (independent variables), $\mathrm{b}_{0}$ is the constant, where the regression line intercepts the $\mathrm{Y}$ axis; $\mathrm{b}_{\mathrm{ith}}(1 \leq \mathrm{i} \leq \mathrm{nth})$ is the standard partial regression coefficient, representing the amount, the response variable $\mathrm{Y}$ changes when the descriptive studied variables changes 1 unit. This represents a model of the system under study, which can be used to investigate which variables influence its response and at what extent, and/or to predict the value of one variable when the others are known. The coefficient of regression $\left(\mathrm{R}^{2}\right)$, had reliable competence between the predicted and measured values, and a higher $\mathrm{R}^{2}$, more than 0.75 , is considered a good indicator of good fit model for stepwise MLR for cumulative metal uptake and studied parameters. Cumulative percentage contributions (CPC) of studied parameter with cumulative metal uptake for each metal was calculated using following equation;

$$
\text { Percentage contribution of specific parameter, } i=\left(\frac{B i}{\sum B i}\right) \times 100
$$

where, $B_{i}=$ MLR coefficient for specific parameter and $\sum B_{i}=$ sum MLR coefficient of all parameters ${ }^{42,43}$.

\section{References}

1. Xia, Y. et al. Ectopic expression of Vicia sativa Caffeoyl-CoA O-methyltransferase (VsCCoAOMT) increases the uptake and tolerance of cadmium in Arabidopsis. Environ Exper Bot 145, 47-53 (2018).

2. Khan, A. H. A. et al. Role of nutrients and illuminance in predicting the fate of fungal mediated petroleum hydrocarbon degradation and biomass production. J Environ Manag 176, 54-60 (2016).

3. He, K. et al. Comparison of soil heavy metal pollution caused by e-waste recycling activities and traditional industrial operations. Environ Sci Pollut R 24, 9387-9398 (2017).

4. Kanwal, U. et al. EDTA ameliorates phytoextraction of lead and plant growth by reducing morphological and biochemical injuries in Brassica napus L. under lead stress. Environ Sci Pollut R 21, 9899-9910 (2014).

5. Majed, N. et al. Food adulteration and bio-magnification of environmental contaminants: A comprehensive risk framework for Bangladesh. Front Env Sci Eng 4, 34 (2016).

6. Alirzayeva, E. et al. Multiple mechanisms of heavy metal tolerance are differentially expressed in ecotypes of Artemisia fragrans. Environ Pollut 220, 1024-1035 (2017).

7. Castro, L. et al. Biosorption of $\mathrm{Zn}$ (II) from industrial effluents using sugar beet pulp and F. vesiculosus: From laboratory tests to a pilot approach. Sci Total Environ 598, 856-866 (2017).

8. Ballester, A. et al. Design of remediation pilot plants for the treatment of industrial metal-bearing effluents (BIOMETAL DEMO project): Lab tests. Hydrometallurgy 168, 103-115 (2017).

9. Wang, X. F. \& Zhou, Q. X. Ecotoxicological effects of cadmium on three ornamental plants. Chemosphere 60, 16-21 (2005).

10. Cui, S. et al. Evaluation of three ornamental plants for phytoremediation of Pb-contamined soil. Int J Phytoremediat 15, 299-306 (2013).

11. Gerats, T. \& Vandenbussche, M. A model system for comparative research: Petunia. Trends Plant Sci 10, 251-256 (2005).

12. Habiba, U. et al. EDTA enhanced plant growth, antioxidant defense system, and phytoextraction of copper by Brassica napus L. Environ Sci Pollut R 22, 1534-1544 (2015).

13. Cornu, J. Y. et al. How do low doses of desferrioxamine B and EDTA affect the phytoextraction of metals in sunflower? Sci Total Environ 592, 535-545 (2017).

14. Grčman, H. et al. EDTA enhanced heavy metal phytoextraction: metal accumulation, leaching and toxicity. Plant Soil 235, 105-114 (2001).

15. Luo, C. et al. Enhanced phytoextraction of $\mathrm{Cu}, \mathrm{Pb}, \mathrm{Zn}$ and $\mathrm{Cd}$ with EDTA and EDDS. Chemosphere 59, 1-11 (2005).

16. January, M. C. et al. Hydroponic phytoremediation of Cd, Cr, Ni, As, and Fe: Can Helianthus annuus hyperaccumulate multiple heavy metals? Chemosphere 70, 531-537 (2008).

17. Chen, H. \& Cutright, T. EDTA and HEDTA effects on Cd, Cr, and Ni uptake by Helianthus annuus. Chemosphere 45, 21-28 (2001).

18. Ivanov, V. et al. Comparative impacts of heavy metals on root growth as related to their specificity and selectivity. Russ J Plant Physiol 50, 398-406 (2003).

19. Yadav, S. Heavy metals toxicity in plants: an overview on the role of glutathione and phytochelatins in heavy metal stress tolerance of plants. S Afr J Bot 76, 167-179 (2010).

20. Sytar, O. et al. Heavy metal-induced oxidative damage, defense reactions, and detoxification mechanisms in plants. Acta Physiol Plant 35, 985-999 (2013).

21. Krantev, A. et al. Treatment with salicylic acid decreases the effect of cadmium on photosynthesis in maize plants. J Plant Physiol 165, 920-931 (2008).

22. Park, J. H. et al. Role of organic amendments on enhanced bioremediation of heavy metal(loid) contaminated soils. J Hazard Mater 185, 549-574 (2011). 
23. Bolan, N. et al. Remediation of heavy metal(loid)s contaminated soils-to mobilize or to immobilize? J Hazard Mater 266, 141-166 (2014).

24. Hegedüs, A. et al. Comparative studies of $\mathrm{H}_{2} \mathrm{O}_{2}$ detoxifying enzymes in green and greening barley seedlings under cadmium stress. Plant Sci 160, 1085-1093 (2001).

25. Pandey, N. \& Sharma, C. P. Effect of heavy metals $\mathrm{Co}^{2+}, \mathrm{Ni}^{2+}$ and $\mathrm{Cd}^{2+}$ on growth and metabolism of cabbage. Plant Sci 163, 753-758 (2002).

26. Van Assche, F. \& Clijsters, H. Effects of metals on enzyme activity in plants. Plant Cell Environ 13, 195-206 (1990).

27. Wang, H. et al. Responses of antioxidative enzymes to accumulation of copper in a copper hyperaccumulator of Commoelina communis. Arch Environ Contam Toxicol 47, 185-192 (2004).

28. Székely, Á. Effect of EDTA on the growth and copper accumulation of sweet sorghum and sudangrass seedlings. Acta Biol Szeged 55, 159-164 (2011).

29. Yuan, M. et al. Molecular and functional analyses of COPT/Ctr-type copper transporter-like gene family in rice. BMC Plant Biol 11, 69 (2011).

30. Williams, L. E. et al. Emerging mechanisms for heavy metal transport in plants. Biochim Biophys Acta 1465, 104-126 (2000).

31. Ishimaru, Y. et al. Zn uptake and translocation in rice plants. Rice 4, 21-27 (2011).

32. Krämer, U. et al. Transition metal transport. FEBS lett 581, 2263-2272 (2007).

33. Li, Y. et al. Two Silene vulgaris copper transporters residing in different cellular compartments confer copper hypertolerance by distinct mechanisms when expressed in Arabidopsis thaliana. New Phytol 215, 1102-1114 (2017).

34. Arshad, M. et al. The reduction of chromium (VI) phytotoxicity and phytoavailability to wheat (Triticum aestivum L.) using biochar and bacteria. Appl Soil Ecol 114, 90-98 (2017).

35. Yahmed, J. B. et al. A simple, fast and inexpensive method to assess salt stress tolerance of aerial plant part: Investigations in the mandarin group. J Plant Physiol 190, 36-43 (2016).

36. Arnon, D. I. Copper enzymes in isolated chloroplasts. Polyphenoloxidase in Beta vulgaris. Plant Physiol 24, 1-16 (1949).

37. Venkatachalam, P. et al. Enhanced plant growth promoting role of phycomolecules coated zinc oxide nanoparticles with P supplementation in cotton (Gossypium hirsutum L.). Plant Physiol Biochem 110, 118-127 (2017).

38. Nishiyama, R. et al. Analysis of cytokinin mutants and regulation of cytokinin metabolic genes reveals important regulatory roles of cytokinins in drought, salt and abscisic acid responses, and abscisic acid biosynthesis. Plant Cell 23, 2169-2183 (2011).

39. Dhindsa, R. S. et al. Leaf senescence: correlated with increased levels of membrane permeability and lipid peroxidation, and decreased levels of superoxide dismutase and catalase. J Exp Bot 32, 93-101 (1981).

40. Maehly, A. The assay of catalases and peroxidases in Methods of Biochemical Analysis 357-424, (Interscience, 1954).

41. Chen, G. X. \& Asada, K. Ascorbate peroxidase in tea leaves: occurrence of two isozymes and the differences in their enzymatic and molecular properties. Plant Cell Physiol 30, 987-998 (1989).

42. Upadhyaya, A. et al. Effect of paclobutrazol on the activities of some enzymes of activated oxygen metabolism and lipid peroxidation in senescing soybean leaves. J Plant Physiol 121, 453-461 (1985).

43. Irzyk, G. P. \& Fuerst, E. P. Purification and characterization of a glutathione S-transferase from benoxacor-treated maize (Zea mays). Plant Physiol 102, 803-810 (1993).

\section{Acknowledgements}

Authors are deeply thankful for Higher Education Commission (HEC) of Pakistan, for funding the principle author Mr. Khan for conducting this research work under Indigenous 5000 PhDs scheme (Funding Number 2AV1-084). Furthermore, we would like to thank Dr. Hassaan Javed, from Department of Plant Sciences, QAU, Pakistan, for providing the spectrophotometry facility.

\section{Author Contributions}

Mr. Aqib Hassan Ali Khan Experimental work and manuscript writing. Dr. Tayyab Ashfaq Butt Guided in designing the experiments and proof reading the manuscript. Dr. Cyrus Raza Mirza Designing the experimental set-up, and statistical analysis. Dr. Sohail Yousaf Helped in biochemical and enzymatic analysis and proof reading the manuscript. Dr. Ismat Nawaz Helped in metal analysis and proof reading the manuscript. Dr. Mazhar Iqbal Developed the idea of the experiment. Supervised all the activities performed during this work. Proof reading of the manuscript.

\section{Additional Information}

Supplementary information accompanies this paper at https://doi.org/10.1038/s41598-019-40540-7.

Competing Interests: The authors declare no competing interests.

Publisher's note: Springer Nature remains neutral with regard to jurisdictional claims in published maps and institutional affiliations.

Open Access This article is licensed under a Creative Commons Attribution 4.0 International License, which permits use, sharing, adaptation, distribution and reproduction in any medium or format, as long as you give appropriate credit to the original author(s) and the source, provide a link to the Creative Commons license, and indicate if changes were made. The images or other third party material in this article are included in the article's Creative Commons license, unless indicated otherwise in a credit line to the material. If material is not included in the article's Creative Commons license and your intended use is not permitted by statutory regulation or exceeds the permitted use, you will need to obtain permission directly from the copyright holder. To view a copy of this license, visit http://creativecommons.org/licenses/by/4.0/.

(C) The Author(s) 2019 